\title{
The meridional temperature gradient in the eastern North Atlantic during MIS 11 and its link to the ocean-atmosphere system
}

\author{
Evgenia S. Kandiano ${ }^{\text {a,* }}$, Henning A. Bauch ${ }^{\text {a,b }}$, Kirsten Fahl ${ }^{\text {c }}$, Jan P. Helmke ${ }^{\text {d, Ursula Röhl }}{ }^{\text {, }}$ \\ Marta Pérez-Folgado ${ }^{\mathrm{f}}$, Isabel Cacho ${ }^{\mathrm{g}}$ \\ a GEOMAR, Wischhofstrasse, 1-3 Kiel, 24148, Germany \\ b Mainz Academy of Sciences, Humanities, and Literature, Germany, GEOMAR, Wischhofstrasse, 1-3 Kiel, 24148, Germany \\ ${ }^{c}$ Alfred Wegener Institut for Polar and Marine Research, 27568 Bremerhaven, Germany \\ d Institute for Advanced Sustainability Studies e.V., Berliner Straße 130, 14467 Potsdam, Germany \\ e MARUM Center for Marine Environmental Sciences, University of Bremen, 28359 Bremen, Germany \\ ${ }^{\mathrm{f}}$ Department of Geology, University of Salamanca, Plaza de la Merced, 37008 Salamanca, Spain \\ g University of Barcelona, Diagonal Sud, Facultat de Geologia c/ Marti Franquès s/n ES-08028 Barcelona, Spain
}

\section{A R T I C L E I N F O}

Article history:

Received 13 May 2011

Received in revised form 29 February 2012

Accepted 10 March 2012

Available online 17 March 2012

\section{Keywords:}

Eastern North Atlantic

Stage 11

North Atlantic Oscillation

Foraminiferal sea surface temperatures

Alkenone sea surface temperatures

\begin{abstract}
A B S T R A C T
Temporal and spatial patterns in eastern North Atlantic sea-surface temperatures (SST) were reconstructed for marine isotope stage (MIS) 11c using a submeridional transect of five sediment cores. The SST reconstructions are based on planktic foraminiferal abundances and alkenone indices, and are supported by benthic and planktic stable isotope measurements, as well as by ice-rafted debris content in polar and middle latitudes. Additionally, the larger-scale dynamics of the precipitation regime over northern Africa and the western Mediterranean region was evaluated from iron concentrations in marine sediments off NW Africa and planktic $\delta^{13} \mathrm{C}$ in combination with analysis of planktic foraminiferal abundances down to the species level in the Mediterranean Sea. Compared to the modern situation, it is revealed that during entire MIS 11c sensu stricto (ss), i.e., between 420 and 398 ka according to our age models, a cold SST anomaly in the Nordic seas co-existed with a warm SST anomaly in the middle latitudes and the subtropics, resulting in steeper meridional SST gradients than during the Holocene. Such a SST pattern correlates well with a prevalence of a negative mode of the modern North Atlantic Oscillation. We suggest that our scenario might partly explain the longer duration of wet conditions in the northern Africa during MIS 11c compared to the Holocene.
\end{abstract}

(c) 2012 Elsevier B.V. All rights reserved.

\section{Introduction}

While it is widely accepted in paleoclimate research that variations in orbital forcing and atmospheric greenhouse gas concentrations are actively involved in glacial-interglacial climate changes, an interglacial climate progression results from the combination of various feedback mechanisms of the land-ocean-atmospheric interaction initiated by some primary factors such as insolation (Berger, 1978; Bonelli et al., 2009).

In recent years, paleoceanographical investigations have been focused on climate dynamics during Marine Isotope Stage 11c (MIS 11c), because the orbital forcing background of this interglacial period shares certain similarities with the Holocene. Both MIS 11c and the Holocene are characterized by low eccentricity, and resulting from this, also by low precessional variations (Berger and Loutre, 2002; Loutre and Berger, 2003). Furthermore, ice cores indicate that CO2 concentrations during MIS 11c were similar to the Holocene, preindustrial

\footnotetext{
* Corresponding author. Tel.: + 49431 6002848; fax: + 494316002961 E-mail address: ekandiano@ifm-geomar.de (E.S. Kandiano).
}

levels (Petit et al., 1999; Epica Member, 2004; Raynaud et al., 2005). However, a comparison of the interglacial climate progress of these two periods in the North Atlantic reveals a number of distinct regional differences in geographical SST patterns and hydrological cycles. For instance, planktic foraminiferal data show that MIS 11c was characterized by warmer SSTs in the middle latitudes (Kandiano and Bauch, 2003; 2007; de Abreu et al., 2005), whereas farther north in the adjacent Nordic seas, interglacial conditions appear to have been rather cold (Bauch et al., 2000; Bauch and Erlenkeuser, 2003; Helmke and Bauch, 2003). By analogy with the modern situation, one can assume that these cold conditions in the Nordic seas may implicate extended sea-ice cover in this region which in turn further influenced oceanatmosphere interactions. In the subtropical NE Atlantic MIS 11c is recognized as a long-lasting period characterized by enhanced vegetation cover over northern Africa (Helmke et al., 2008). Although these climate conditions were probably comparable to the early Holocene Wet African Period, the cause for a rather prolonged duration during MIS 11c remains obscure considering those concepts that suggest the dynamics of precessional changes be the main modulator of monsoonal intensity (Prell and Kutzbach, 1987; McIntyre et al., 1989; Schefuß et al., 2003). 
Because geographical SST patterns and evaporation/precipitation processes are strongly related to atmospheric circulation through changes in atmospheric pressure gradients, we intend to use detailed SST reconstructions in combination with precipitation-related records in order to investigate the ocean-atmospheric interaction during MIS 11c. As known from modern conditions, atmospheric circulation in the North Atlantic region is dominated by the North Atlantic Oscillation (NAO), a seesaw of sea level pressure between subtropical anticyclone and subpolar low pressure system, and is characterized by strong interannual to multidecadal variability (Barnston and Livezey, 1987; Hurrell, 1995). Although meteorological observational data allow investigation of NAO regularities only for the last 150 years, computer simulations have already indicated the existance of changes of NAO indices at least on multi-centennial time scales (Semenov et al., 2008). Moreover, paleoceanographical studies postulated a significant influence of the NAO on regional climate conditions for longer, suborbital to orbital timescales maintaining the analogy to the present-day conditions (Keigwin and Pickart, 1999; Rimbu et al., 2003; Felis et al., 2004; Kim et al., 2004; Bout-Roumazeilles et al., 2007). Following these ideas, we also refer to the modern general scheme of North Atlantic atmospheric circulation, assuming an existence of NAO-like oscillations during MIS 11c and using the modern scheme as a template in order to make some assumptions about ocean-atmospheric interaction during this period. To enable this, we reconstructed interglacial climate dynamics in polar, middle, and low latitudes of the eastern North Atlantic during MIS 11c, calculated meridional SST gradients and reconstructed moisture regime in the Mediterranean region. Further, we extend our reconstructions to atmospheric circulation, because the NAO variability is strongly related to geographic SST patterns and impacts hydrological cycles in European and West African sector (Hurrell, 1995; Rodwell et al., 1999; Bader and Latif, 2003).

So far, direct high-resolution SST records in the North Atlantic during MIS 11c are still very scarce (de Abreu et al., 2005; Kandiano and Bauch, 2007; Martrat et al., 2007; Stein et al., 2009; Voelker et al., 2010). In order to examine SST gradients in the North Atlantic a submeridional transect of five core sites was selected for the current investigations. Our SST reconstructions are based on planktic foraminiferal census data and alkenones. These data are further supported by benthic and planktic $\mathrm{O}$ - and $\mathrm{C}$-isotope records and, at subpolar and polar sites, by ice-rafted debris (IRD) content and iron concentrations off NW Africa. Additionally, abundances of planktic foraminiferal species representing certain water masses were analyzed separately from conventional foraminiferal census counts following the strategy already applied during previous investigations (Kandiano and Bauch, 2002; Bauch and Kandiano, 2007).

\section{Regional atmospheric-oceanographic conditions}

The main axes of wind and storm track directions in the North Atlantic range between a subzonal and a submeridional orientation. The changes in between these two atmospheric "endmembers" are depending on the strength of atmospheric pressure gradients between the Iceland-low and the Azores-high which is calculated as NAO indices. A positive NAO mode is characterized by increased pressure gradients between Iceland-low and Azores-high (Hurrell, 1995). This results in stronger westerlies which favors increased Atlantic warm water advection into the Nordic Seas, also leading to wet conditions over the northern Europe and dry conditions over North Africa. In the Nordic Seas, the positive NAO mode is associated with relatively high SSTs and a reduced ice cover (Dickson et al., 2000). Decreased pressure gradients are related to a negative NAO mode, resulting in weaker westerlies and a more zonal storm track direction which cause an increased moisture flux to the North African and Mediterranean region and drier conditions in northern Europe. At the same time, in the Nordic Seas a SST decrease and advances of the ice cover are observed. Correspondingly, both observations and computer simulations show a strong correlation between a geographical SST distribution in the North Atlantic, a precipitation/ evaporation intensity, an ice cover in the Nordic Seas, and a NAO index (Hurrell, 1995; Rodwell et al., 1999; Dickson et al., 2000). A negative NAO mode is associated with steep meridional SST gradients over the eastern North Atlantic; by contrast, the positive NAO mode is characteristic for lower meridional SST gradients. Meteorological data from the past about 150 years point to the general dominance of a positive NAO (Jones et al., 1997; Osborn, 2006). Some oceanographical observations indicate that present-day NAO changes have an impact also on the deep water convection intensity: under a positive NAO mode deep convection in the Labrador Sea becomes more intense, while the negative one fosters convection in the Nordic seas (Dickson et al., 1996).

\section{Core study sites}

\subsection{M23414, MD992277/PS1243, M23063}

Core sites M23414, MD992277/PS1243 and M23063 underlie the northward continuation of the Gulf Stream (Fig. 1, Table 1). Core site M23414 is situated in the middle latitudes under the western edge of the North Atlantic Current (NAC), southward from where the Irminger Current (IC) branches off the NAC. The position of core site M23414 enables us to record changes in warm water input of the NAC and its possible deflections from the modern position. Moreover, core M23414 is highly suitable for SST reconstructions, because in the middle latitudes difference in SST values between pronounced interglaciation is quite small. Therefore, the past changes are better detectable at the NAC margins, than under its main axis (McManus et al., 1999; Kandiano and Bauch, 2003).

Core sites PS1243/MD992277 and M23063 are located in the Nordic Seas. The Atlantic waters enter the Nordic Seas eastward from Iceland as the Norwegian Current (NC) and westward from Iceland as the North Iceland Current (NIC), a continuation of the IC. In the modern environments, the NC transports a much larger volume of Atlantic waters in comparison to the NIC. Core site M23063 directly underlies the NC, which carries the Atlantic waters farther north into the Arctic Ocean. Core site PS1243/MD992277 is situated in the central Nordic Seas westward from the NC, in the area where the Atlantic waters of the NC mix up with the polar waters transported by the East Greenland Current (EGC). MIS 11c was investigated in core MD992277 which has a good time resolution, while the Holocene reconstructions come from trigger boxcore PS1243 from roughly the same position.

\subsection{ODP Site 958}

Site 958 is located in the subtropical Northeast Atlantic off Northwest Africa (Fig. 1; Table 1), under the eastern edge of the Canary Current which is a part of the subtropical gyre. Today, this site is influenced by regional coastal upwelling induced by the trade winds (Johnson and Stevens, 2000). The changes in the surface water circulation at this site are therefore strongly related to the regional atmospheric variability, which is defined by two counterparting seasonal wind systems: the $\mathrm{NE}$ trade winds that reach their maximum intensity during the northern winter season, and the West African monsoon that is strongest during the northern summer (Fig. 1). These changes are related to the meridional migration of the Intertropical Convergence Zone (ITCZ) (e. g. Wooster et al., 1976; Nykjær and van Camp, 1994). Because the trade wind intensity affects both upwelling of cold waters and lateral water advection from the relatively cold Canary Current in the north, changes over longer timescales should be captured by our SST proxies (Hughes and Barton, 1974; Fischer et al., 1996).

The pelagic sediments off NW Africa clearly reflect the glacialinterglacial pattern due to changes in wind-driven terrigenous input (Tiedemann et al., 1994; Pflaumann et al., 1998). Because glacial times were characterised by a reduced intensity of the West African monsoon and enhancement of the trade wind strength, the glacial sediment 


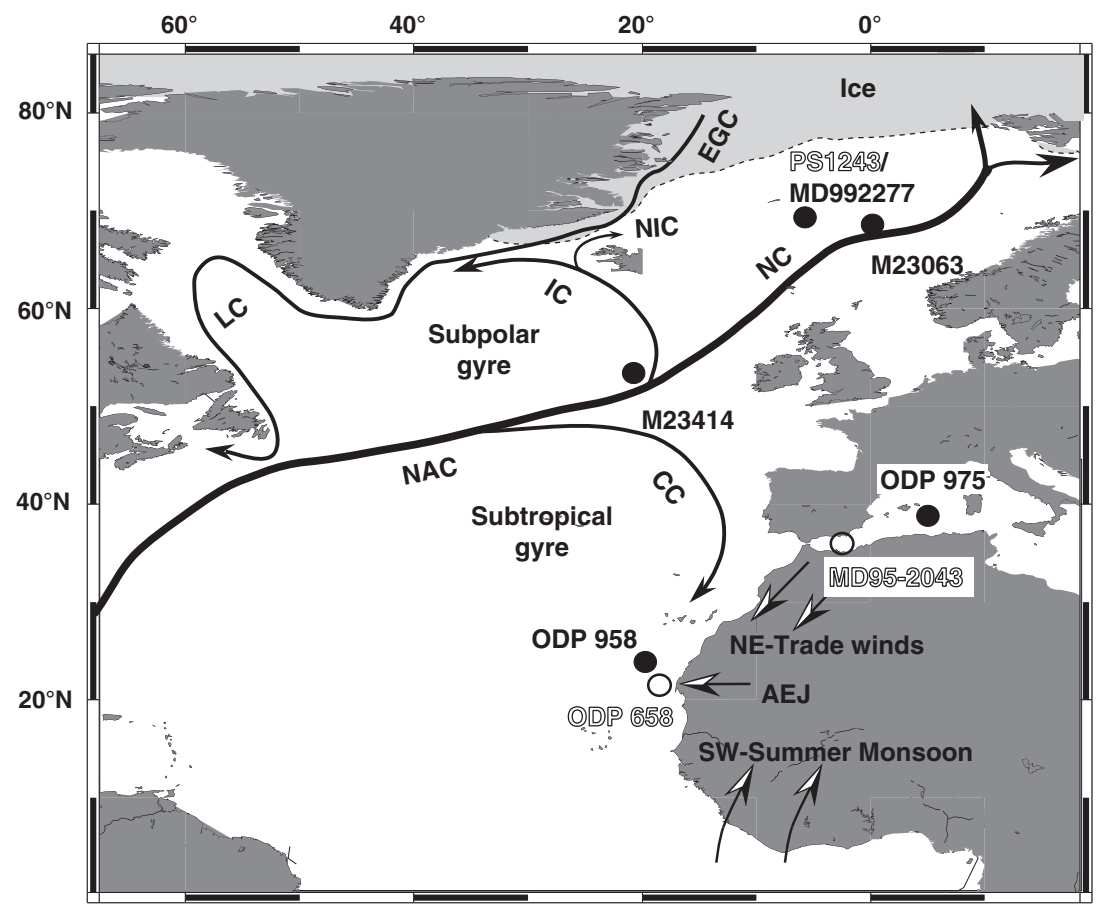

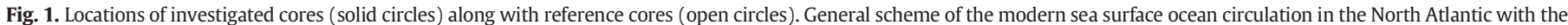

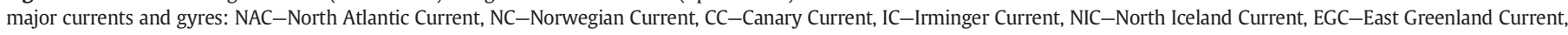

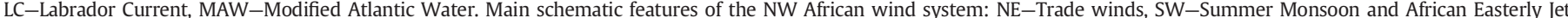

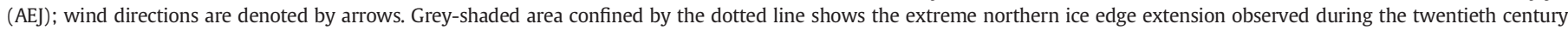
(April, 1995; Vinje, 2001).

intervals contain sufficiently more of an eolian fraction in comparison to the interglacial sections (Tjallingii et al., 2008). For better evaluation data of SST and faunal composition of MIS 11c from Site 958 were compared to those of the Holocene from ODP Site 658 which is located nearby (Fig. 1; Table 1; Zhao et al., 1995; deMenocal et al., 2000a).

\subsection{ODP Site 975}

Site 975 is located in the western part of the Mediterranean Sea on the slope of the South Balearic-Islands basin (Fig. 1; Table 1). The western part of the Mediterranean Sea is affected at the surface by Modified Atlantic Water. This area shows high sensitivies to a changeable precipitation regime, as the Mediterranean Sea is an almost closed basin where presently evaporation exceeds precepitation causing higher salinities here than in the adjacent Atlantic region (Levitus and Boyer, 1994). Our MIS 11c SST records of Site 975 were compared to the Holocene SST records from core MD95-2043 from the Alboran Sea (Fig. 1; Table 1; Cacho et al., 1999).

\section{Material and methods}

\subsection{Planktic foraminiferal census counts and foraminiferal SST calculations}

A minimum of 300 planktic foraminiferal test was identified in every considered sample. Following the strategy of Pflaumann et al. (1996) Neogloboquadrina pachyderma dextral (d) and intergrades between N. pachyderma (d) and N. dutertrei as well as Globorotala menardii and G. tumida were grouped together to avoid taxonomic controversies. The left and right-coiling forms of Globorotalia truncatulinoides were counted separately due to their different environmental preferences (Herman, 1972; Barash, 1988). More recently, genetic investigations have revealed the existence of several cryptic species combined under the morphotype G. truncatulinoides, which provided an explanation for the geographical separation of left and right-coiling forms (de Vargas et al., 2001). In all cores the planktic foraminiferal census counts were executed using the mesh size $>150 \mu \mathrm{m}$. In addition to conventional counts, in cores from the Nordic Seas (PS1243/MD992277 and M23063), we also considered the smaller size fraction $>80 \mu \mathrm{m}$ (for core M23063 besides that also sediment size fraction $>125 \mu \mathrm{m}$

Table 1

Geographical locations and water depth of the investigated cores with references for the Holocene data. (R)-Reference core.

\begin{tabular}{|c|c|c|c|c|c|c|}
\hline \multirow[t]{2}{*}{ Core } & \multirow[t]{2}{*}{ Geographical coordinates } & \multirow[t]{2}{*}{ Water depth (m) } & \multicolumn{2}{|c|}{ Period presented } & \multicolumn{2}{|c|}{$\begin{array}{l}\text { Source of alkenone/foraminiferal SST and foraminiferal } \\
\text { counts for the Holocene }\end{array}$} \\
\hline & & & & MIS 11 & Alkenone SST & Foraminiferal counts \\
\hline MD992277 & $69^{\circ} 15^{\prime} \mathrm{N} ; 06^{\circ} 19^{\prime} \mathrm{W}$ & 2800 & & + & Not represented & Not represented \\
\hline PS1243 (R) & $69^{\circ} 22^{\prime} \mathrm{N} ; 06^{\circ} 32^{\prime} \mathrm{W}$ & 2710 & + & & This study & Kandiano and Bauch (2002) \\
\hline M23063 & $68^{\circ} 45^{\prime} \mathrm{N} ; 00^{\circ} 00^{\prime} \mathrm{W}$ & 2299 & + & + & This study & This study \\
\hline M23414 & $53^{\circ} 32^{\prime} \mathrm{N}, 20^{\circ} 17^{\prime} \mathrm{W}$ & 2196 & + & + & This study & Kandiano and Bauch (2003) \\
\hline ODP975 & $38^{\circ} 54^{\prime} \mathrm{N} ; 4^{\circ} 31^{\prime} \mathrm{E}$ & 2415 & & + & Not represented & Not represented \\
\hline MD95-2043 (R) & $36^{\circ} 09^{\prime} \mathrm{N} ; 2^{\circ} 37^{\prime} \mathrm{W}$ & 1841 & + & & Cacho et al. (1999) & Pérez-Folgado et al. (2003) \\
\hline ODP 958 & $23^{\circ} 59^{\prime} \mathrm{N} ; 20^{\circ} 00^{\prime} \mathrm{W}$ & 3795 & & + & Not represented & Not represented \\
\hline ODP $658(\mathrm{R})$ & $20^{\circ} 45^{\prime} \mathrm{N} ; 18^{\circ} 35^{\prime} \mathrm{W}$ & 2263 & + & & Zhao et al. (1995) & deMenocal et al. (2000b) \\
\hline
\end{tabular}


was counted). This method was applied because the traditionally used size fraction $>150 \mu \mathrm{m}$ is represented during periods of cooler conditions by an almost monospecific assemblage of $N$. pachyderma sinistral (s). However, considerable amounts of warm-water-indicative species might still be found in smaller size fractions (Kandiano and Bauch, 2002). Thus, counting certain smaller size fractions allows for capturing also climatic changes under cooler conditions, because subpolar species such as Turborotalita quinqueloba are known to occur in smaller test sizes under decreased SSTs (Bauch, 1994; Kandiano and Bauch, 2002).

In addition to conventional counts, so-called rare planktic foraminiferal species were also considered in core M23414 (Kandiano and Bauch, 2007). Although they represent accessory species in this particular environment and cannot be embedded into SST reconstructions because of their very low total abundance, these species still serve as excellent indicators for changes in warm water input. At present, they normally inhabit warmer waters of the tropical-subtropical latitudes but may be brought northward to the core site via the NAC during times of enhanced water advection. The counts on the rare species were performed using much larger subsamples in comparison to conventional counting technique. To evaluate changes in warm water input into the middle latitudes the three tropical-to-subtropical species Globigerinoides ruber (w), Globorotalia truncatulinoides (s) and (d) were selected.

At Site 975 in the Mediterranean Sea relative abundances of Globigerinoides ruber and Globorotalia inflata were analysed to obtain information about past changes in precipitation regime. Here, as well as in the Caribbean Sea, the relative abundances of these two species appear to exhibit an inverse correlation to salinity (Pérez-Folgado et al., 2003; Martinez et al., 2007).

Foraminiferal SSTs for core M23414 were calculated using the North Atlantic subset of the coretop data base as compiled by Pflaumann et al. (2003). To reconstruct SSTs at Sites 975 and 958 and their Holocene reference cores (MD95-2043 and 658, respectively) a combined set of 279 samples from the Mediterranean Sea (Kucera et al., 2005 and references therein) and from the Iberian margin (Salgueiro et al., 2008) was added to the aforementioned data base. To reach consistency between foraminiferal counts produced by different researchers pink and white forms of Globigerinoides ruber, as well as Globigerinoides sacculifer and Globigerinoides trilobus, were grouped together. Two different mathematical techniques were applied to convert planktic foraminiferal compositions to SSTs: Modern Analogue Technique (MAT; Hutson, 1980; Prell, 1985), and Revised Analogue Technique (RAM; Waelbroeck et al., 1998). Additionally, foraminiferal SSTs at Site 958 and Site 658 were calculated once again with species Neogloboquadrina pachyderma dextral (d) and Neogloboquadrina dutertrei grouped together. This was done to avoid uncertainties of taxonomical concepts related to $N$. pachyderma intergrades, the individuals which represent a transition form between these two species and may be attributed to one of them, depending on the degree of their test development. Therefore, the taxonomical boundary between these two species is quite subjective. In this respect we analysed the foraminiferal abundances at ODP Site 958 and Site 658 and it seems that in our foraminiferal counts and in those of deMenocal et al. (2000a) the boundary between taxonomical concepts of $N$. pachyderma dextral (d) and $N$. dutertrei may differ. Additionally, we have noted enhanced fragmentation of foraminiferal tests at Site 958 which may imply a dissolution effect. Therefore, we have established a dissolution index for this core by counting foraminiferal fragments and calculating their percent in relation to intact foraminiferal tests.

Foraminiferal SSTs for the two polar sites, cores M23063 and MD992277/PS1243, were calculated using a modification of MAT, i.e., SIMMAX (Pflaumann et al., 1996, 2003). It has been shown that, due to a special approach in calculating similarity indices, SIMMAX may yield quite objective results for the higher latitudes. A total number of 947 coretop samples were used as reference data set (Pflaumann et al., 1996, 2003).

Bearing in mind that NAO is essentially a winter season signal, we considered SST gradients between polar and middle/low latitudes by also using the winter foraminiferal SSTs. In the case of foraminiferalderived SSTs, SST gradients were calculated by subtracting SIMMAXSST values (polar sites) from the average of RAM and MAT (middle and low-latitude sites) for each considered case. Because foraminiferal abundances at Site 958 appear affected by dissolution to some degree, meridional SST gradients were also calculated from alkenones. In core M23063 foraminiferal counts were carried out also from the Holocene section while the other Holocene foraminiferal records were taken from previous studies (Table 1; deMenocal et al., 2000a; Kandiano and Bauch, 2002, 2003; Pérez-Folgado et al., 2003).

\subsection{Alkenone analysis and SSTs}

For alkenone analyses, the freeze-dried and homogenised sediments were extracted with an Accelerated Solvent Extractor (DIONEX, ASE 200; $100{ }^{\circ} \mathrm{C}, 1000 \mathrm{psi}$ ), using dichloromethane as solvent. The separation of compounds was carried out by open column chromatography $\left(\mathrm{SiO}_{2}\right)$ using $n$-hexane and dichloromethane $(1: 1, v / v)$ and dichloromethane. The composition of alkenones was analysed with a Hewlett Packard gas chromatograph (HP 6890, column $60 \mathrm{~m} \times 0.25 \mathrm{~mm}$; film thickness $0.25 \mu \mathrm{m}$; liquid phase: DB1-MS), using a temperature program as follows: $60{ }^{\circ} \mathrm{C}$ (3 min), $150{ }^{\circ} \mathrm{C}$ (rate: $20^{\circ} \mathrm{C} / \mathrm{min}$ ), $320^{\circ} \mathrm{C}$ (rate: $6{ }^{\circ} \mathrm{C} / \mathrm{min}$ ), $320^{\circ} \mathrm{C}$ (40 min isothermal). For splitless injection a cold injection system (CIS) was used $\left(60{ }^{\circ} \mathrm{C}(6 \mathrm{~s}), 340{ }^{\circ} \mathrm{C}\right.$ (rate: $\left.12{ }^{\circ} \mathrm{C} / \mathrm{s}\right), 340{ }^{\circ} \mathrm{C}(1 \mathrm{~min}$ isothermal). Helium was used as a carrier gas $(1.2 \mathrm{ml} / \mathrm{min})$. Individual alkenone $\left(C_{37: 4}, C_{37: 3}, C_{37: 2}\right)$ identification is based on retention time and comparison with an external standard, which was also used for controlling the nstrument stability.

The alkenone unsaturation index $\left(\mathrm{U}^{\mathrm{k}^{\prime}}{ }_{37}\right)$ as proxy for SST (Brassell et al., 1986; Prahl and Wakeham, 1987) was calculated following the relationship between $\mathrm{U}^{\mathrm{k}^{\prime}}{ }_{37}$ and temperature proposed by Müller et al. (1998), based on a global core-top calibration $\left(60^{\circ} \mathrm{N}-60^{\circ} \mathrm{S}\right) \mathrm{U}^{\mathrm{k}^{\prime}}{ }_{37}=$ $0.033 \mathrm{~T}\left({ }^{\circ} \mathrm{C}\right)+0.044$. In this case the standard error of the calibration is reported as $+/-0.050 \mathrm{U}^{\mathrm{k}^{\prime}}{ }_{37}$-units or $+/-1.5^{\circ} \mathrm{C}$ (Müller et al., 1998). Replicate measurements of the used alkenone standard revealed an internal measurement accuracy better than $0.5^{\circ} \mathrm{C}$. As the tetra-unsaturated alkenone $\left(\mathrm{C}_{37: 4}\right)$ becomes more significant with decreasing temperature (e.g., Rosell-Melé et al., 1994), for cores PS1243/MD992277 the calibration published by Rosell-Melé et al. (1995; core-top calibration, $2^{\circ} \mathrm{S}-75^{\circ} \mathrm{N}$ ) was used due to the presence of these tetra-unsaturated compounds. Although alkenone SSTs reflect mean annual temperatures at the investigated sites, for the calculated alkenone SSTs of the northernmost cores in particular, we want to point out that the records of long-chain unsaturated alkenones in high-latitude, low-temperature areas are difficult to interpret and often discussed (e.g., Conte and Eglinton, 1993), mainly due to a less good fit of the calibration curve below $5{ }^{\circ} \mathrm{C}$. Thus, our results should be assessed as an estimation which, however, appears to be permissible when combined with the other data. In cores PS1243, M23063 and M23414 alkenone SST records were also obtained for the Holocene sections while for low latitudes Holocene alkenone SST records were taken from the literature (Table 1; Zhao et al., 1995; Cacho et al., 1999). Information about the Holocene alkenone SST records taken for the comparison is summarized in Table 1.

\subsection{Stable isotope measurements, IRD and Fe concentration}

Benthic isotopes at Site 958 and in core M23414 were measured on epifaunal species Cibicidoides wuellerstorfi (5-10 specimens; 250-500 $\mu \mathrm{m})$. In cores MD992277 and M23063 the benthic isotope records were performed on Oridorsalis umbonatus (25 specimens, $125-250 \mu \mathrm{m})$. Planktic isotopes were measured on N. pachyderma (s) for the two polar cores M23063 and MD992277 (20-30 specimens, $150-250 \mu \mathrm{m}$ ), and on Globigerina bulloides for cores M23414, Site 975, and Site 958 (10-15 specimens). In addition, we also analyzed the species G. ruber (white) (15 specimens) at Sites 975 and 958. Isotope measurements were performed at Stable Isotope Labor at 
IFM-GEOMAR (Kiel) and in Stable Isotope Leibniz Labor (University of Kiel), using a Finnigan MAT 253 mass spectrometer system and a Finnigan MAT 251 mass spectrometer, respectively. All measurements were calibrated on the Vienna Pee Dee Belemnite isotope scale (VPDB).

To retrieve information on ice-sheet disintegration phases, which are especially characteristic for glacial-interglacial transitional periods, IRD was counted in cores MD992277 (>250 $\mu \mathrm{m}), \operatorname{M} 23063(>250 \mu \mathrm{m})$ and M23414 (>150 $\mu \mathrm{m})$. Data of iron intensities at Site 958 were used as a proxy for aeolian input (Helmke et al., 2008). XRF Core Scanner data were collected every $2 \mathrm{~cm}$ down-core over a $1 \mathrm{~cm}^{2}$ with slit size of $10 \mathrm{~mm}$ using a generator setting of $20 \mathrm{kV}, 0.087 \mathrm{~mA}$ and a sampling time of 15 seconds directly at the split core surface of the archive half with XRF Core Scanner I at the MARUM, University of Bremen. The split core surface was covered with a polypropylene foil in order to avoid contamination of the XRF measurement unit and desiccation of the sediment. The here reported data have been acquired by XRF Core Scanner I at MARUM using a KEVEX Psi Peltier Cooled Silicon Detector and a KEVEX X-ray Tube 52500008-02 with the target material molybdenum (Mo). The detection limit for iron for the XRF scanner used is 210 ppm (Richter et al. 2006). Repeatability tests at the surface of split sediment core halves have shown that the error is smaller than $1 \%$ if the core surface is of high quality (Röhl and Abrams, 2000), which was the case for the scanned core sections of this study.

\subsection{Age control}

MIS 11c period was recognised in all cores during previous investigations (core M23063-Bauch, 1997; core MD992277-Helmke et al., 2005; core M23414-Helmke and Bauch, 2001; Helmke and Bauch, 2003; Site 975-Pierre et al., 1999; Site 958-Pflaumann et al., 1998). The age control for cores M23414 and Site 958 was established by synchronising the benthic $\delta^{18} \mathrm{O}$ records of each core to a global stack chronology (Lisiecki and Raymo, 2005).

An initial age model of sediment core from Site 975 was published by Pierre et al. (1999) using a low-resolution planktic $\delta^{18} \mathrm{O}$ record of G. bulloides-benthic foraminifera are not present in the studied core interval. After our re-sampling at much denser intervals, a revised age model needed to be produced using the $\delta^{18} \mathrm{O}$ records of the two species G. bulloides and G. ruber (w).

The original age model of core MD992277 was established on the basis of Ca counts, CaCO3-content and $\delta^{18} \mathrm{O}$ data measured on N. pachyderma (s) (Helmke et al., 2005). The age model was then improved using the newly established benthic $\delta^{18} \mathrm{O}$ records.

In core M23063, the interval of MIS 11c was clearly recognizable during previous investigations on the basis of low resolution planktic $\delta^{18} \mathrm{O}$ data (Vogelsang, 1990; Bauch, 1997) and sediment reflectance grey level (Bauch and Helmke, 1999). The original low resolution planktic record by Vogelsang (1990) was updated in this study by new measurements at closer intervals. Furthermore the records of M23063 are easily correlatable with cores PS1243/MD992277 and PS1246 using $\delta^{13} \mathrm{C}$ of $N$. pachyderma (s), IRD and $\mathrm{CaCO} 3$ contents (Vogelsang, 1990; Bauch et al., 2001a). Also the older age model for the Holocene part of core M23063 could be improved on the basis of the newly produced records of IRD and stable isotope data.

The derived age models for the foraminiferal SST samples during period of MIS 11c full-interglacial conditions yielded an average time resolution of 1152 years at Site 958, 636 years at Site 975, 346 years in core M23414, 1700 years in core M23063, and 811 years in core MD992277.

\section{Results}

\subsection{Records of oxygen isotopes and IRD}

In cores from Sites 958 and 975, sharp changes in planktic and benthic $\delta^{18} \mathrm{O}$ towards lighter values are registered between 434 and $420 \mathrm{ka}$, a time interval which defines the period of Termination $V$. Records from our other cores presumably start within Termination V (Fig. 2). In core MD992277 from the Nordic Seas, benthic $\delta^{18} 0$ produced on Oridorsalis umbonatus show large-amplitude fluctuations of up to $1.07 \%$ o during Termination V (Fig. 2). Such strong fluctuations in benthic $\delta^{18} \mathrm{O}$ are a distinct feature, particularly, of deglacial events in the Nordic Seas (Veum et al., 1992; Dokken and Jansen, 1999; Rasmussen et al., 1999; Bauch et al., 2001b), whereas full-interglacial periods, as well as glacial inceptions, are not affected by such fluctuations allowing for a conventional use of the benthic $\delta^{18} \mathrm{O}$ for stratigraphic purposes (Bauch and Erlenkeuser, 2003). In all cores, $\delta^{18} 0$ values indicate that the main deglacial transition came to an end at approximately $420 \mathrm{ka}$. In cores M23414 from middle latitudes and cores MD992277 and M23063 from the Nordic Seas, this time is also associated with a steep IRD decrease.

Between 420 and approximately $411 \mathrm{ka}$, benthic and planktic $\delta^{18} \mathrm{O}$ continued to decrease or experienced large fluctuation (Site 975) in all our cores. The period between 411 and $398 \mathrm{ky}$ is characterized by more stable, plateau-like benthic $\delta^{18} \mathrm{O}$ values, which may be regarded as the time of the global sea level highstand. At Site 975 the two planktic $\delta^{18} \mathrm{O}$ data show large fluctuations of up to $1.2 \%$ and $0.9 \%$, respectively, during the early interglacial phase between 420 and $411 \mathrm{ka}$.

Coherent changes of all benthic $\delta^{18} \mathrm{O}$ records towards heavier values started approximately at $398 \mathrm{ka}$, which reflects the beginning of a new glacial inception (Fig. 2). At the same time, planktic $\delta^{18} \mathrm{O}$ increases at low and middle latitudes were observed. In core M23414, the first noticeable spike of IRD is recorded at $390 \mathrm{ka}$, lagging these $\delta^{18} \mathrm{O}$ changes by $3 \mathrm{ky}$. Whereas in both polar cores, M23063 and MD 992277, planktic $\delta^{18} \mathrm{O}$ records exhibit increases already at $407 \mathrm{ka}$, i.e., earlier than in the lower latitudes. IRD content at high latitudes also started to rise again earlier than in core M23414. Thus, in all cores the $\delta^{18} \mathrm{O}$ records provide a good basis to identify the period when full-interglacial conditions prevailed during MIS 11c, i.e. MIS 11c sensu stricto (ss). According to our age models that particular time lasted from 420 to $398 \mathrm{ka}$. For convenience hereafter this period will be named as MIS 11c. Differences among the planktic $\delta^{18} \mathrm{O}$ records within this period, on the other hand, likely reflect variations in the interglacial climate dynamics between low and high latitudes.

\subsection{Records of SST and planktic foraminifera}

There is a consistent offset in absolute values between foraminiferal and alkenone SST records in each investigated core which increases from the subtropics to the polar region (Fig. 3). Within MIS 11c, the difference between the two records changes from $\sim 4{ }^{\circ} \mathrm{C}$ in Sites 958 and 975 , to $\sim 9{ }^{\circ} \mathrm{C}$ in core MD 992277 (the comparison is based on the RAM SST estimates for the three former cores). This latitudedependent increase between the two SST sets may indicate a seasonal offset between the two proxy carriers, coccolithophorids and foraminifera. Without neglecting the alkenone SSTs trends, for our further analysis we will mainly rely on winter foraminiferal SST estimates as the NAO is primarily a winter season signal (Hurrell, 1995).

At Sites 958, 975, and in core M23414 both faunal-derived and alkenone-derived SSTs show trends similar to the planktic $\delta^{18} \mathrm{O}$ records (Figs. 3, 4), with increasing temperatures during Termination $\mathrm{V}$ and a progressive decrease again during glacial inception. During MIS 11c, SSTs in these cores exhibit their warmest interglacial values. Furthermore, all SST records from the middle and low latitudes reveal two phases which is also in close agreement with the trends in planktic $\delta^{18} \mathrm{O}$ : From 420 to approximately $411 \mathrm{ka}$, SSTs continued to rise; the maximum SST level was reached during the second phase, between 411 and $398 \mathrm{ka}$.

Because of the consistent SST increase during the early phase of MIS $11 \mathrm{c}$ in all cores, it seems reasonable to interpret SST values for the two periods separately. Further we compare our SST results to the Holocene SST reconstructions also subdividing the Holocene period into the early, 


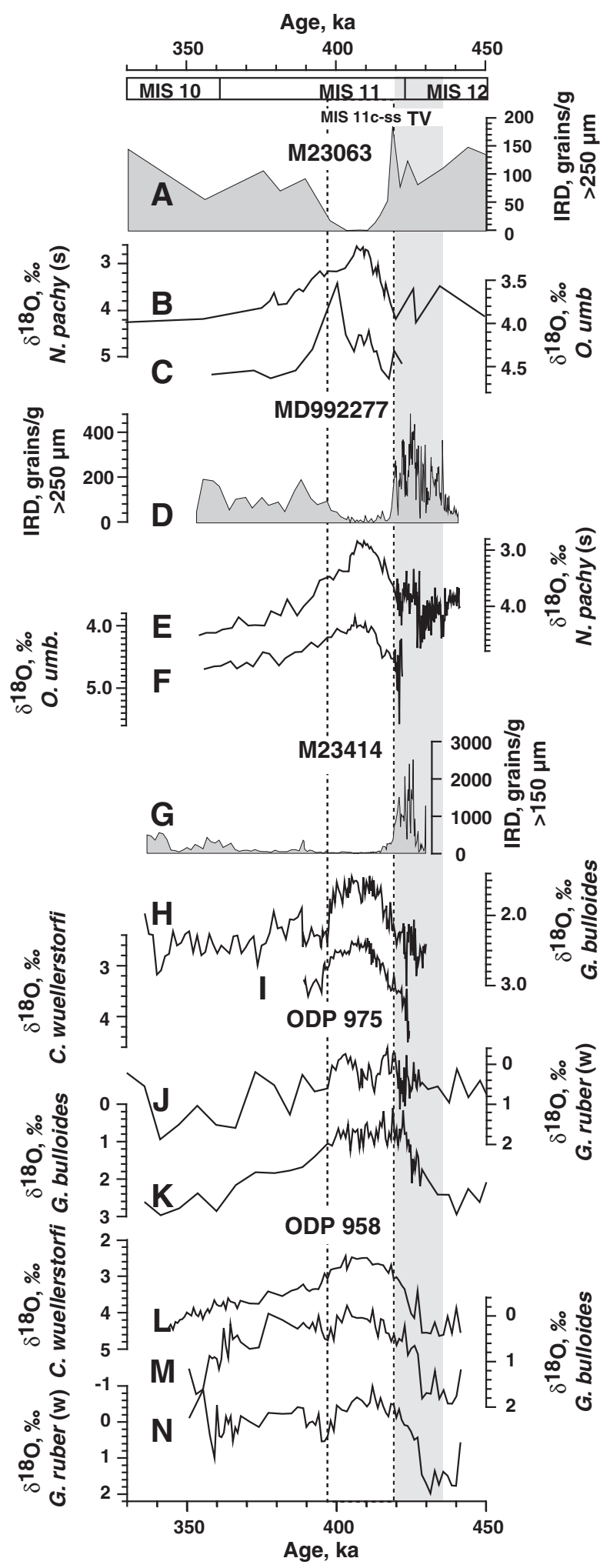

Fig. 2. Stratigraphically relevant data for all studied cores. IRD, planktic and benthic $\delta^{18} \mathrm{O}$ A, B, C-in core M23063; D, E, F-in core MD992277; G, H, I-in core M23414; J, K-two planktic $\delta^{18} \mathrm{O}$ records at Site 975; L, M-benthic and two planktic $\delta^{18} \mathrm{O}$ records at Site 958. Stratigraphical subdivision is shown on the upper panel. MIS 11c-ss is indicated by dotted lines. Grey bar marks Termination V.

postglacial phase (11-5.5 ka), which also represents the Holocene SST optimum, and the late phase (5.5-0 ka) during which a progressive cooling trend was already registered in the North (Bauch et al., 2001b).
All maximum and average values of MIS 11c as well as the reference Holocene SST records are summarised in Table 2.

As seen in enhanced fragmentation of foraminiferal tests at Site 958 the assemblages data abundances are affected by dissolution during the total period of MIS 11c (Figs. 3, 4), probably causing the higher dissimilarity indices and communality values (Fig. 4). Because significant interglacial SST decreases in this core coincide with enhanced dissolution indices, we considered these decreases as artefacts and excluded them from our SST comparison. At both polar sites, SST records (except foraminiferal SSTs in core MD992277) show very sharp increases immediately before their maximum values were reached (Fig. 3). In core M23063, foraminiferal and alkenone SSTs, as well as the reduction in abundance of polar species Neogloboquadrina pachyderma (s) down to $75.7 \%$ ( size fraction $>80 \mu \mathrm{m}$ ), indicate that the SST optimum of MIS $11 \mathrm{c}$ in polar latitudes was centred around $409-410 \mathrm{ky}$. This maximum appears of short duration since it already ended at about $405 \mathrm{ka}$ (Fig. 3). In core MD992277 foraminiferal SSTs do not reveal a clear SST optimum due to considerable variability. However, the decrease in abundance of polar species N. pachyderma (s) down to $66.5 \%$ (in size fraction $>80 \mu \mathrm{m}$ ) clearly marks the period when peak warmth must have occurred (Fig. 3). The "noisiness" of foraminiferal SST record in core MD992277 may be explained by almost absence of subpolar species other than T. quinqueloba and by the increased error at the cold end of the foraminiferal SST method (e.g. Pflaumann et al., 1996), something which seems inherent to most SST proxy tools in the polar regions

In spite of the mentioned methodological limitations, our foraminiferal data and SST reconstructions clearly indicate that surface conditions in the Nordic Seas during MIS11c were cooler than in the Holocene, whereas in the middle and low latitudes an opposite interglacial SST pattern is revealed (Figs. 3, 4; Table 2). This opposing regional SST pattern seems less clear based on the alkenone data. Further support for a major latitude-dependent interglacial contrast comes from the foraminiferal species data in core M23414 (Kandiano and Bauch, 2007) and at Sites 658/958 (Fig. 4). In core M23414 thermophilic representatives such as Globorotalia truncatulinoides (d), (s), and G. ruber $(\mathrm{w})$, although belonging to the rare species group, show considerably higher values during MIS 11c than in the Holocene (up to $9.8 \%$, $6.6 \%$, $2.5 \%$ vs. $5.0 \%$, $2.0 \%$, and $0.4 \%$, respectively; Fig. 4). Similar situation is found at Sites 658/958 where the most thermophilic species/ taxons (Globigerinoides ruber, Globigerinoides sacculifer/Globigerinoides trilobus, and Globorotalia tumida/Globorotalia menardii) exhibit higher abundances during MIS 11c than in the Holocene (up to 19.5\%, 7.3\%, and $5.8 \%$ vs $14.8 \%, 7.0 \%$, and $2.4 \%$; Fig. 4 ).

Based on the foraminiferal data the reconstructed SST gradients between the polar and middle latitudes reached $5-7^{\circ} \mathrm{C}$ for the Holocene and $9-10{ }^{\circ} \mathrm{C}$ during MIS $11 \mathrm{c}$, while between the polar latitudes and the western Mediterranean Sea they were $9-12^{\circ} \mathrm{C}$ and $14-15^{\circ} \mathrm{C}$, respectively (Table 3). Maximum winter SST gradients are registered between the Nordic seas and off Africa: $13-16{ }^{\circ} \mathrm{C}$ during the Holocene and $17-19{ }^{\circ} \mathrm{C}$ during MIS11c-ss. Thus, this comparison implies that MIS 11c was characterised by steeper SST gradients in comparison to the Holocene.

\subsection{Humidity-related proxies from cores off Africa and Mediterranean region}

Relative increases in iron content at Site 958, which are related to an enhanced input of dust from a dry NW Africa continent during colder times (Helmke et al., 2008), exhibit a pronounced peak during the early phase of Termination V (centred at $429 \mathrm{ka}$ ). Thereafter, values decreased reaching their minimum level around $420 \mathrm{ka}$ (Fig. 5). Between 420 and $409 \mathrm{ka}$, iron intensities remained generally low as well, from 409 ka onwards there is a gradual dust increase again until around $382 \mathrm{ka}$ when a pronounced iron peak regained the values of Termination V. The gradual increase in iron intensities towards the end of MIS11c is coincident with a decrease of warm components of foraminiferal assemblages (Fig. 5). Around 389 ka the group Globorotalia 
Age, ka

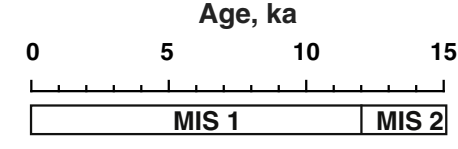

PS1243

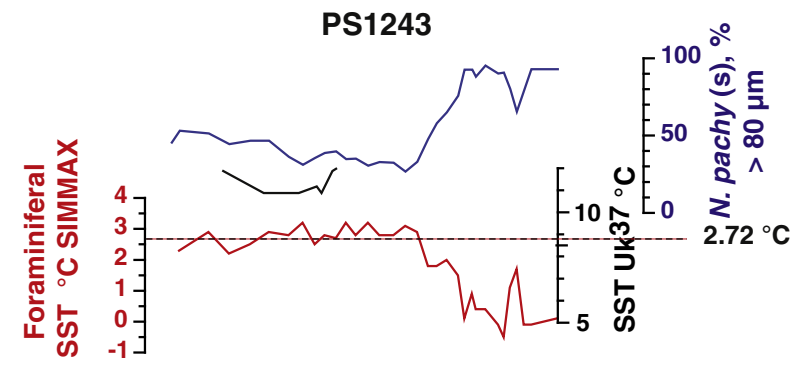

M23063

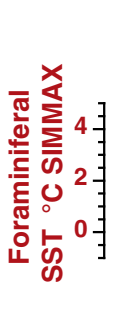

트

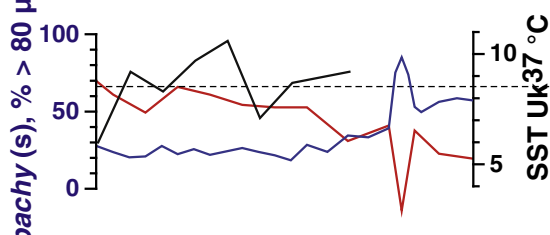

$z$

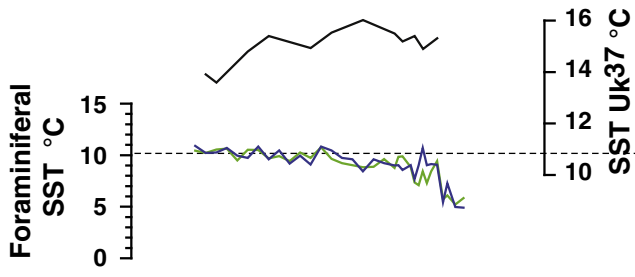

MD95-2043

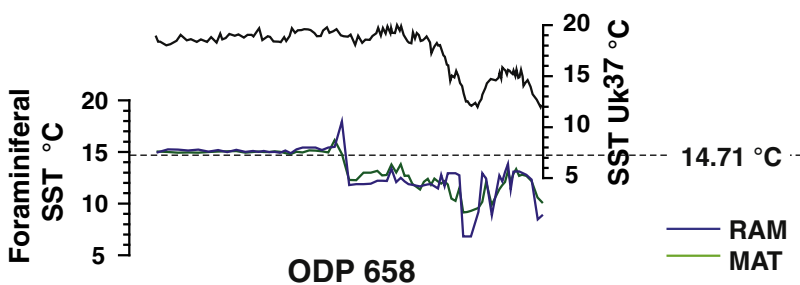

ODP 658
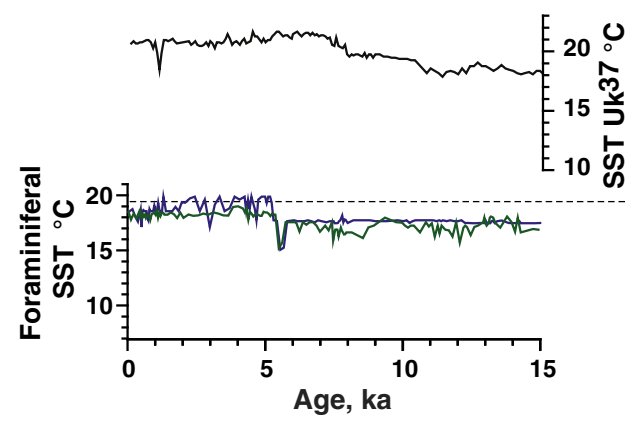

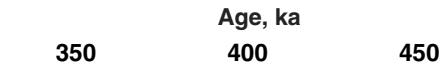

\begin{tabular}{|l|l|l|}
\hline MIS 10 & \multicolumn{3}{|c|}{ MIS 11 } \\
\hline \multicolumn{3}{|c|}{ MIS 11c-ss } \\
\hline \multicolumn{3}{|c|}{ MIS 12 } \\
\hline
\end{tabular}

MD992́277

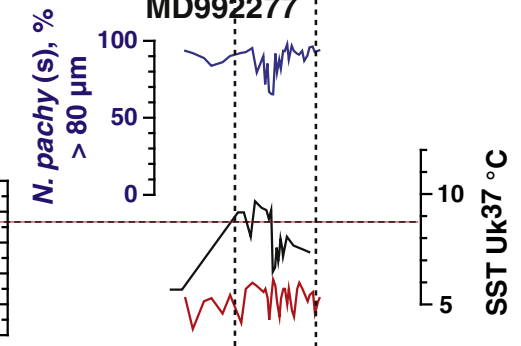

$4.44^{\circ}$

$\begin{array}{ccc} & & \\ \text { RAM } & 5 & 5 \\ \text { MAT } & 5 & 0\end{array}$

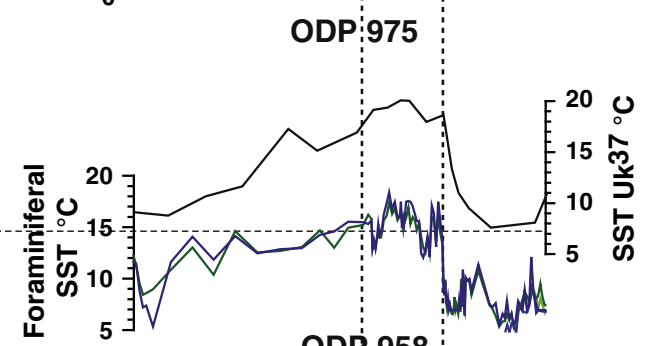

ODP 958

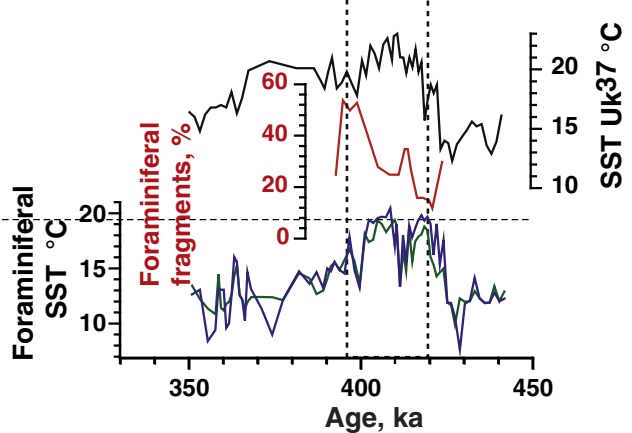

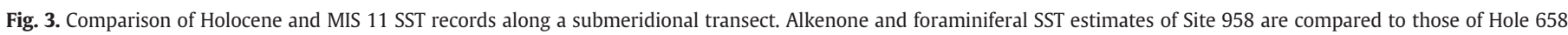

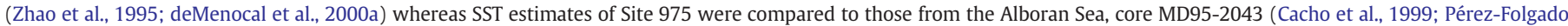

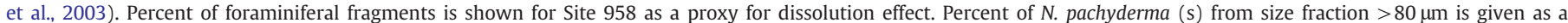

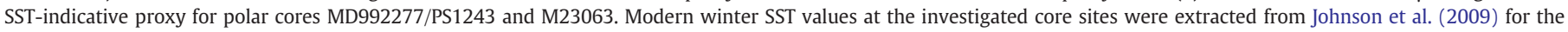
time period 1970-2008 with a positive NAO mode (dotted lines). Stratigraphical subdivision is given on the upper panel. MIS 11c-ss is indicated by dotted lines.

tumida/Globorotalia menardii completely ceased while Globigerinoides sacculifer and Globigerinoides. ruber decreased significantly. The main peak of iron intensities that followed is contemporaneous with a decrease in foraminiferal SSTs, which is best recognized in the RAM record (Fig. 3).
At core Site 975 , the early period of MIS $11 \mathrm{c}$ is marked by high fluctuations in planktic $\delta^{18} \mathrm{O}$ as it was mentioned above. These fluctuations are generally contemporaneous with strong negative excursions of $\delta^{13} \mathrm{C}$ in both species, Globigerinoides ruber and Globigerina bulloides, implying 


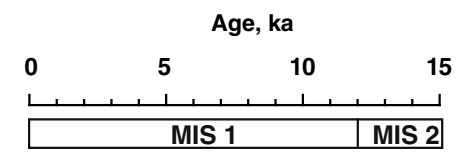

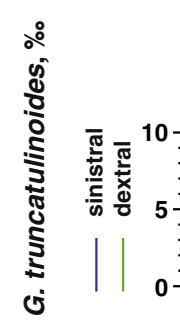
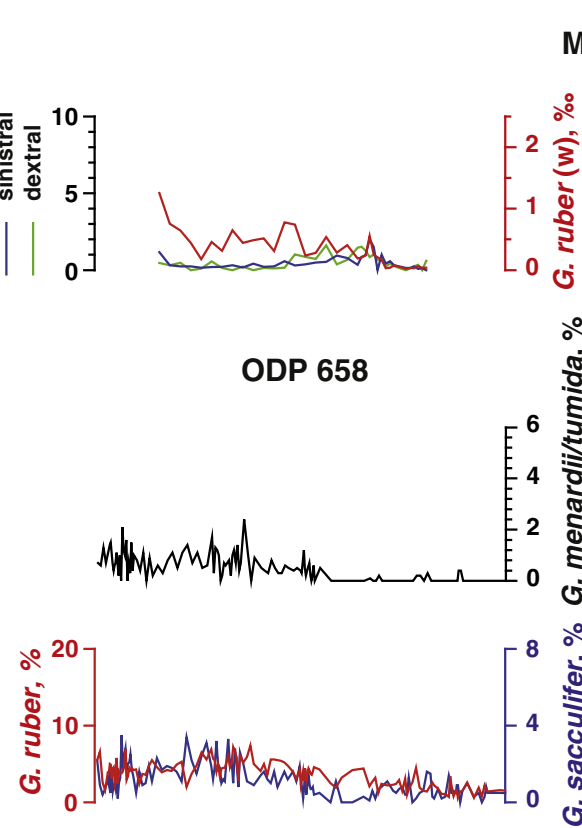

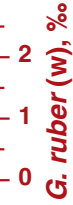

\section{(1)}

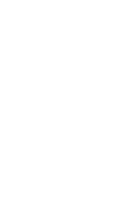

ㅇำ

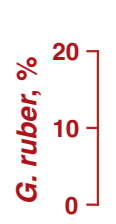

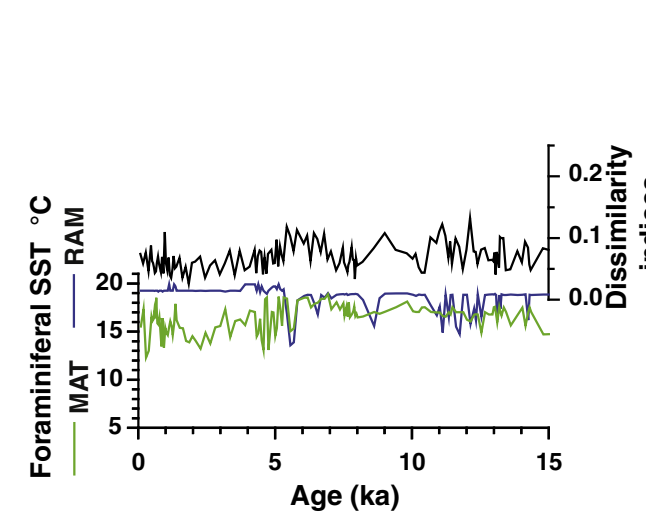
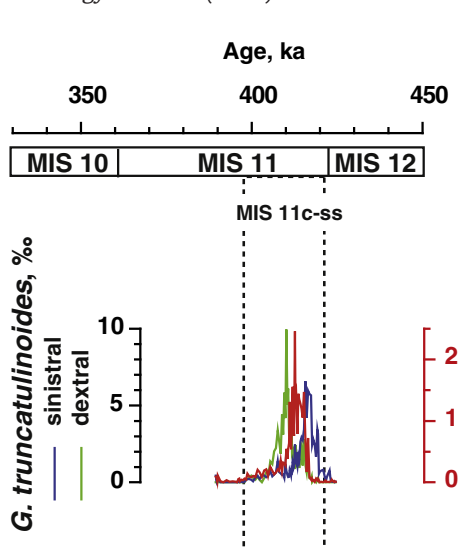

MIS 11c-ss

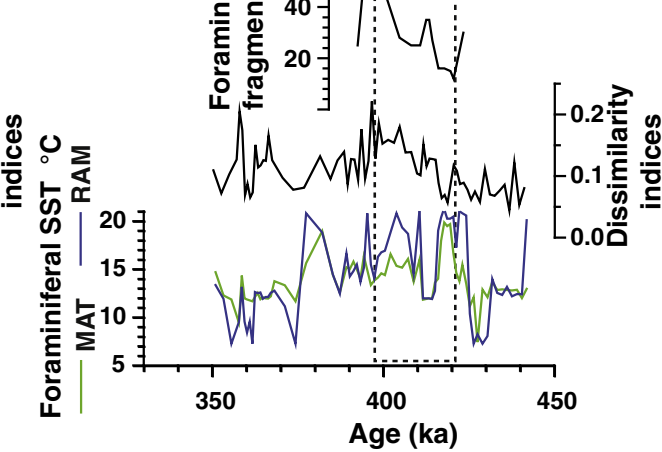

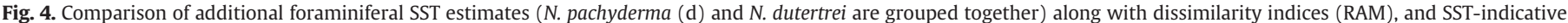

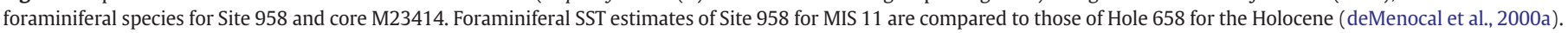

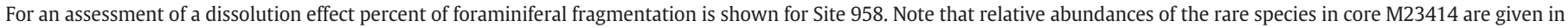
per mil. Stratigraphical subdivision is given on the upper panel. MIS 11c-ss is indicated by dotted lines.

a strong stratification of the water column (Fig. 5). At the same time two typical interglacial representatives, G. ruber and Globorotalia inflata show a characteristic opposite relation (Fig. 5). Between 420 and approximately $398 \mathrm{ka} \mathrm{G}$. ruber reveals a pronounced spike with a maximum of $19.3 \%$ around $410 \mathrm{ky}$, whereas G. inflata exhibits comparatively low values down to $6.9 \%$. Towards the end of MIS 11c, relative abundance of G. ruber decreases down to 3.2\% while G. inflata reaches $37.1 \%$.

\section{Discussion}

Orbital similarities between MIS 11c and the Holocene are based on a certain configuration of parameters with a cyclicity of about $400 \mathrm{ky}$. A dampened eccentricity characteristic for both intervals resulted in diminished precessional variations and, therefore, a decreased insolation in the high latitudes (Berger, 1978). According to modelling experiments, insolation impulse during Termination $\mathrm{V}$ was somewhat weak to drive glacial climate quickly towards full-interglacial conditions (Imbrie et al., 1993; Li et al., 1998). Additionally, European ice-sheet expansion was very large during MIS 12 (Donner, 1995), a fact which might help to explain not only the exceptional length of Termination V (Oppo et al., 1998; Bauch et al., 2000; Billups et al., 2004; Healey and Thunell, 2004; de Abreu et al., 2005) but also the difference in SST dynamics between polar and middle/low latitudes as revealed by us for the early interglacial phase. Our foraminiferal and alkenone SST data clearly demonstrate that the subtropical and the temperate climate zones experienced abrupt warming in accordance with insolation changes directly after Termination V. Such an early response to warming agrees with other investigations from the N. Atlantic (Oppo et al., 1998; McManus et al., 1999; 2003; de Abreu et al., 2005; Stein et al., 2009; Voelker et al., 2010; Rodrigues et al., 2011) and continental surroundings (Desprat et al., 2005; Nitychoruk et al., 2005; de Vernal and Hillaire-Marcel, 2008). On the contrary, the steep SST rise as registered in the Nordic Seas much later (around $410 \mathrm{ka}$ ) was driven, at least partially, by the second insolation peak (Fig. 6). This significant delay in the establishment of warmest conditions in the Nordic Seas probably resulted from very specific surface ocean properties in the North - i.e., freshened by extensive ice-sheet melting causing enhanced expansion 
Table 2

SSTs for the Holocene and MIS 11c. Comparison is made separately for the early and late phases of the Holocene and MIS 11c. Higher values are highlighted in bold.

\begin{tabular}{|c|c|c|c|c|}
\hline \multirow{3}{*}{ SST method } & \multicolumn{4}{|l|}{ SST } \\
\hline & Early phase Holocene & Early phase MIS 11 & Late phase Holocene & Late phase MIS 11 \\
\hline & $(11-5.5 \mathrm{ky})$ & $(420-411 \mathrm{ky})$ & $(5.5-0 \mathrm{ky})$ & (411-398 ky) \\
\hline \multicolumn{5}{|l|}{ PS1243/D992277 } \\
\hline Forams SST SIMMAX maximal & 3.20 & 0.70 & 2.90 & 0.80 \\
\hline Forams SST SIMMAX average & 2.61 & 0.19 & 2.60 & 0.33 \\
\hline Alkenone SST maximal & 12.20 & 8.1 & 11.90 & 9.70 \\
\hline Alkenone SST average & 11.42 & 7.68 & 11.40 & 8.12 \\
\hline \multicolumn{5}{|l|}{ M23063 } \\
\hline Forams SST SIMMAX maximal & 4.60 & 1.40 & 3.70 & 3.20 \\
\hline Forams SST SIMMAX average & 4.12 & 0.10 & 3.30 & 1.28 \\
\hline Alkenone SST maximal & 10.7 & 9.10 & 9.8 & 8.7 \\
\hline Alkenone SST average & 9.8 & 8.53 & 8.4 & 8.17 \\
\hline \multicolumn{5}{|l|}{ M23414 } \\
\hline Forams SST RAM maximal & 10.93 & 11.04 & 10.99 & 11.27 \\
\hline Forams SST RAM average & 9.42 & 9.98 & 10.38 & 10.53 \\
\hline Forams SST MAT maximal & 10.86 & 10.79 & 10.73 & 11.00 \\
\hline Forams SST MAT average & 9.11 & 10.13 & 10.30 & 10.62 \\
\hline Alkenone SST maximal & 16.01 & 15.83 & 15.39 & 16.03 \\
\hline Alkenone SST average & 14.46 & 14.03 & 13.62 & 14.83 \\
\hline \multicolumn{5}{|l|}{ M95-2043/ODP 975} \\
\hline Forams SST RAM maximal & 17.94 & 17.27 & 15.24 & 18.18 \\
\hline Forams SST RAM average & 13.34 & 14.57 & 15.07 & 15.52 \\
\hline Forams SST MAT maximal & 16.07 & 16.17 & 15.01 & 17.5 \\
\hline Forams SST MAT average & 13.47 & 14.56 & 14.94 & 15.37 \\
\hline Alkenone SST maximal & 19.90 & 18.19 & 19.61 & 19.21 \\
\hline Alkenone SST average & 18.24 & 17.87 & 18.63 & 19.62 \\
\hline \multicolumn{5}{|l|}{ ODP 658/ODP 958} \\
\hline Forams SST RAM maximal & 18.19 & 19.8 & 19.91 & 20.44 \\
\hline Forams SST RAM average & 17.57 & 18.75 & 18.91 & 19.22 \\
\hline Forams SST MAT maximal & 18.02 & 19.04 & 19.05 & 19.48 \\
\hline Forams SST MAT average & 17.02 & 17.42 & 18.33 & 18.70 \\
\hline Alkenone SST maximal & 21.50 & 23.00 & 21.50 & 22.79 \\
\hline Alkenone SST average & 20.25 & 20.10 & 20.63 & 20.97 \\
\hline Additional forams SST RAM maximal & 18.19 & 19.77 & 19.91 & 19.88 \\
\hline Additional forams SST RAM average & 17.61 & 18.63 & 18.77 & 19.62 \\
\hline Additional forams SST MAT maximal & 17.35 & 19.65 & 18.77 & 20.01 \\
\hline Additional forams SST MAT average & 16.33 & 17.35 & 16.71 & 19.05 \\
\hline
\end{tabular}

of seasonal sea-ice (Bauch et al., 2000), which in turn must have had a strong feedback also on the spatial configuration of the oceanatmosphere system over the North Atlantic region.

\subsection{Dynamics of sea-surface property in the Nordic Seas}

Between 420 and $411 \mathrm{ka}$ and during times of comparatively weak insolation forcing at $65^{\circ} \mathrm{N}$, the Nordic Seas region was still influenced by deglacial effects due to ongoing input of meltwater from still existing ice caps (Figs. 3,6). Although the abrupt decrease in IRD input after 420 ka would indicate a strong reduction in iceberg availability, the Nordic Seas were still occupied by cold surface water masses. Moreover, a persistence of some IRD in both cores also after the main deglaciation combined with light values of planktic $\delta^{18} \mathrm{O}$, low SSTs, and high proportions of Neogloboquadrina pachyderma (s) even in the smaller size fraction implies the presence of a rather fresh ocean surface and thus the likelihood of expanded winter sea-ice coverage at our core sites (Figs. 2, 3). This latter assumption gains support from our foraminiferal counts of $>125 \mu \mathrm{m}$ sediment size fraction from core M23063, showing that during this period the polar species $N$. pachyderma (s) fluctuates above 90\% (Bauch, 1997; data not shown). Because in the modern environment such a high abundance of $N$. pachyderma (s) roughly corresponds to the maximal extent of winter sea-ice cover (Johannessen et al., 1994), we assume that during the early interglacial phase, i.e. until $411 \mathrm{ky}$, sea ice in the Nordic Seas also expanded far eastward and southward from its modern position (Fig. 1). The lower surface salinity promoted enhanced stratification and together with more expansive winter sea-ice cover, contributed to a maintenance of cold conditions. Such surface ocean properties also reduced the surface flux of warm
Atlantic water through the Nordic Seas and farther north into the Arctic Ocean.

SSTs in the Nordic Seas reached their peak interglacial values only during the late phase of MIS 11c, between 411 and 405 ka (Figs. 3, 6). SSTs and foraminiferal assemblages in both conventional and small size fractions at site M23063, where currently warm Atlantic water masses prevail, would indicate the proximity of the sea-ice edge even during the interglacial peak. The slight increase of planktic $\delta^{18} \mathrm{O}$ at site MD992277 during the late interglacial phase of MIS 11c very likely reflects a salinity increase due to a replacement of polar waters by warmer and more saline Atlantic waters (Fig. 2). This assumption is corroborated by both high alkenone SST values and a low relative abundance of the Neogloboquadrina pachyderma (s) in the smaller size fraction during this time. A similar timing in sea-surface dynamics is recognized for the last interglacial (MIS 5e) when the climate optimum occurred also during the second half of MIS 5e (Bauch and Erlenkeuser, 2008; Van Nieuwenhove et al., 2011). During the present interglacial, on the contrary, the Nordic Seas experienced the SST optimum early, directly after Termination I until the Mid-Holocene (e.g., Bauch et al., 2001a, 2001b; Calvo et al., 2002; Andersson et al., 2010).

\subsection{Dynamics of sea-surface properties in the lower latitudes}

At Site 958, Termination V was not only accompanied by a considerable SST increase it was also affected by significant changes in precipitation regime (Helmke et al., 2008)., The pronounced peak of iron concentrations between 431 and 424 ka reflects very arid conditions over North-West Africa at the beginning of Termination V (Fig. 5). The abrupt change of this arid phase towards more moist conditions during 
Table 3

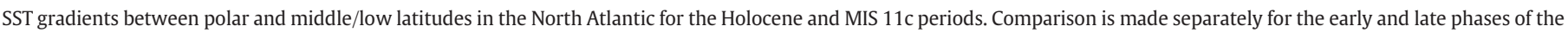

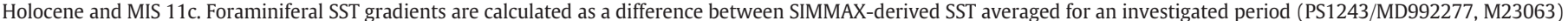
and a mean of RAM and MAT values averaged for an investigated period (M23414, MD95-2043/Site 975, 658/Site 958). Steeper SST gradient values are highlighted in bold.

\begin{tabular}{|c|c|c|c|c|}
\hline \multirow{3}{*}{ SST methods } & \multicolumn{4}{|l|}{ SST gradients } \\
\hline & Early phase Holocene & Early phase MIS 11 & Late phase Holocene & Late phase MIS 11 \\
\hline & $(11-5.5 \mathrm{ky})$ & $(420-411 \mathrm{ky})$ & (5.5-0 ky) & (411-398 ky) \\
\hline \multicolumn{5}{|l|}{ PS1243/MD992277-M23414 } \\
\hline Foraminiferal SST gradients & 6.07 & 9.36 & 7.74 & 9.78 \\
\hline \multicolumn{5}{|l|}{ M23063-M23414 } \\
\hline Foraminiferal SST gradients & 5.15 & 9.95 & 7.04 & 9.30 \\
\hline \multicolumn{5}{|l|}{ PS1243/MD992277-MD95-2043/ODP 975} \\
\hline Foraminiferal SST gradients & 10.80 & 14.37 & 12.41 & 15.12 \\
\hline \multicolumn{5}{|l|}{ M23063-MD95-2043/ODP 975} \\
\hline Foraminiferal SST gradients & 9.28 & 14.65 & 11.71 & 14.17 \\
\hline \multicolumn{5}{|l|}{ PS/1243/MD992277-ODP658/ODP958 } \\
\hline Foraminiferal SST gradients & 14.69 & 17.90 & 16.02 & 18.63 \\
\hline Foraminiferal alternative SST gradients & 14.36 & 17.80 & 15.14 & 19.01 \\
\hline Alkenone SST gradients & 8.83 & 12.60 & 9.23 & 12.87 \\
\hline \multicolumn{5}{|l|}{ M23063-0DP658/ODP958 } \\
\hline Foraminiferal SST gradients & 13.18 & 17.99 & 15.32 & 16.68 \\
\hline Foraminiferal alternative SST gradients & 12.85 & 17.89 & 14.44 & 18.06 \\
\hline Alkenone SST gradients & 11.20 & 11.93 & 12.04 & 12.44 \\
\hline
\end{tabular}

the later terminations is also characteristic for glacial-interglacial transitions in general, and is the result of geographical shifts and intensifications changes within the West African Monsoon system (Balsam et al., 1995; Pflaumann et al., 1998; Tjallingii et al., 2008). Like in the early Holocene monsoon intensification over NW Africa during the early phase of MIS 11c was probably related to a northward-moving ITCZ, which caused a weakening of the trade winds and, accordingly, a decrease in coastal upwelling intensity (Adkins et al., 2006; Weldeab et al., 2007). Due to the combined effects of vegetation cover/enhanced precipitation and diminished trade wind strength, total dust flux off NW Africa is reduced when North Atlantic SSTs rise and vice versa (e.g., Tjallingii et al., 2008). A northward shift in the ITCZ is apparently promoted by changes in insolation during obliquity increases and precession decreases (Tuenter et al., 2003). But a direct comparison between MIS 11 and the Holocene in this respect is difficult, because of a different phasing in these orbital parameters (Berger, 1978). However, one could assume that during the early MIS 11c the ITCZ was situated more south than in the Holocene due to a certain delay in precessional cycle. Another factor which could also cause more southern placement of the ITCZ is a more extensive ice coverage in the Nordic seas (Chiang and Bitz, 2005).

Modern observations show that increases in upwelling intensity off NW Africa arenegatively correlated with SSTs (Fischer et al., 1996). Because Site 958 is affected by coastal upwelling (Johnson and Stevens, 2000) we can assume that a substantial part of the SST increase during the early interglacial phase of MIS 11c reflects a successive weakening of the coastal upwelling cell caused by weakened trade wind strength. As such conditions are contemporaneous with wetter conditions on land, the period between 420 and $409 \mathrm{ka}$ is therefore directly comparable with the African Wet Period of the early Holocene (deMenocal et al., 2000a, b; Adkins et al., 2006; Helmke et al., 2008; Tjallingii et al., 2008).

Evidence of increased humidity conditions during the early phase of MIS $11 \mathrm{c}$ is also embedded in marine sediment proxy records of the western Mediterranean region. The strong decrease in iron concentrations, noticed at Site 958 at the end of Termination V, might correspond to an interval of a drastic decrease in the $\delta^{13} \mathrm{C}$ of the two planktic foraminiferal species Globigerina bulloides and Globigerinoides ruber at Site 975 (Fig. 5). In general, decreases of planktic $\delta^{13} \mathrm{C}$ are characteristic for episodes when carbon isotope exchange between subsurface ocean layer and atmosphere is distorted due to, for instance, enhanced stratification which affects vertical mixing. Such a situation may occur during an intensification of moisture supply, when increased river runoff and precipitation provides an excess of fresh water to the region, thereby enhancing surface ocean stratification. Similar decreases in $\delta^{13} \mathrm{C}$ values at Site 975 have also been described during the early Holocene period when moist conditions prevailed at the continent (Jimenez-Espejo et al., 2008). Because the high-amplitude fluctuations in the $\delta^{18} \mathrm{O}$ registered during this period cannot be explained by SST fluctuations alone, they point to salinity changes as a cause (Fig. 5). The noticeable difference in the amplitude of $\delta^{18} \mathrm{O}$ variability of these two planktic species could be explained by variations in their seasonal preferences. As shown by previous investigations, G. bulloides has the highest abundance during April-May whereas G. ruber experiences its bloom during highest monsoonal intensity in summer (Pujol and Grazzini, 1995; Bárcena et al., 2004).

The abundance increase of Globigerinoides ruber in conjunction with low abundance of Globorotalia inflata at Site 975 during the time of low $\delta^{13} \mathrm{C}$ gives further evidence of surface water freshening in the study region (Fig. 5). G. ruber is known to be quite tolerant to salinity reductions. For instance, in the southern Caribbean Basin G. ruber is the dominant species of the freshwater lense environment caused by the Orinoco river discharge (Schmuker and Schiebel, 2002) and has demonstrated increases in abundance in response to enhanced freshwater input (Martinez et al., 2007). Contrary to G. ruber, G. inflata thrives under normal salinity conditions as during its life cycle this species undergoes vertical migrations from shallow to intermediate water depths with low vertical salinity gradients (Martinez et al., 2007). A similar inverse correlation between these two species, as noticed by us for MIS 11c, is also recognized in various cores from the western Mediterranean basin for the Holocene African Wet Period (Pérez-Folgado et al., 2003). Our data do not allow to speculate in detail about the origin of increased moisture supply embedded in the 975 records. In the western Mediterranean Sea low surface salinity conditions might became established also by increased river runoff which resulted from melting of southern European and/or NW African (Atlas) mountain glaciers (Rogerson et al., 2008). Moreover, the western Mediterranean "sapropels" are by analogy less expressed than their eastern counterparts, and their appearance may not be strictly synchronous either (Rogerson et al., 2008). However, we do not rule out an influence of the West African monsoon because evidence of freshwater input at Site 975 seems to coincide in time with its operation.

At both our southern Sites 958 and 975, the glacial-to-interglacial changes in humidity-indicative proxies as described above were contemporaneous with an abrupt SST increase, driven by orbital dynamics. In good agreement with the Holocene climate evolution modelling experiments have demonstrated an intensification of summer monsoon 


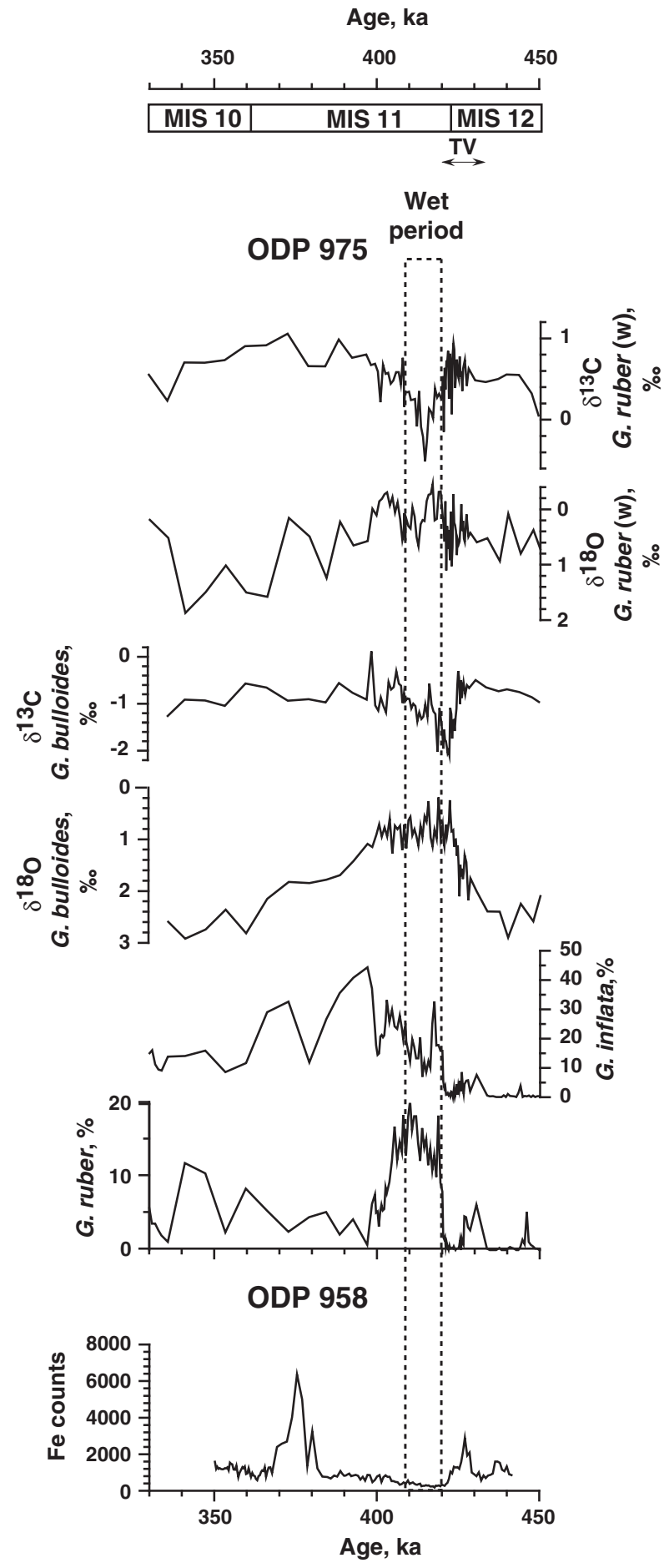

Fig. 5. Comparison of Fe concentrations, a proxy for a West African monsoon activity, at Site 958 along with planktic oxygen isotopes and relative abundances of G. ruber (w) and G. inflata, humidity-indicative species, at Sites 975. The period of maximal wet conditions is marked as "Wet period" and shown by dotted lines. Termination V (TV) is indicated by the arrow. Stratigraphical subdivision is given on the upper panel.

activity in response to precession-forced changes (Claussen et al., 1999; Schefuß et al., 2003, Marzin and Braconnot, 2009). Proxy data indicate that the Holocene Wet African Period (12 to $5.5 \mathrm{ka}$ ) coincided with the regional climate optimum and major insolation change (deMenocal et al., 2000a, b; Adkins et al., 2006; Tjallingii et al., 2008). For MIS 11c, however, we find a somewhat different relation: Wet conditions lasted almost twice as much longer in comparison to the
Holocene, from 420 to $409 \mathrm{ka}$, and passed through an insolation minimum (Fig. 6). In fact, the slowly increasing iron concentrations after 409 ka would imply that still relatively humid conditions continued to exist in the NW African region.

Our SST reconstructions reveal a warm SST anomaly in the middle and low latitudes off Africa during MIS 11c as compared to the Holocene. Moreover, in the middle latitudes not only quantitative SST reconstructions but also analysis of relative abundances of the rare thermophilic species implies that the middle latitudes were also warmer during MIS 11c than during the Holocene (Kandiano and Bauch, 2003; 2007). These results are consistent with other SST records published so far (Table 4; Ruddiman et al., 1989; Martrat et al., 2007; Lawrence et al., 2009; Stein et al., 2009; Rodrigues et al., 2011). An exception is Site 980 which shows very similar SST values for MIS 1 and MIS 11 (McManus et al., 1999). However, the method of SST estimates employed in that latter study involved changes in global ice volume which might have introduced further uncertainties, as different ice-volume reconstructions show controversial results for MIS 11 (Rohling et al., 1998; Hearty et al., 1999; McManus et al., 2003; Kandiano and Bauch, 2007). Our data show that the SST optimum in the subtropical as well as in the middle latitudes was reached during the late phase which is consistent with previously published foraminiferal and alkenone SST data of MIS 11c from the wider North Atlantic region (de Abreu et al., 2005; Martrat et al., 2007; Stein et al., 2009; Rodrigues et al., 2011; Stein et al., 2009) .

\subsection{Ocean-atmospheric circulation in the North Atlantic during MIS $11 \mathrm{c}$}

When comparing the modern geographical SST distribution in the North Atlantic (Levitus and Boyer, 1994) with our overregional SST reconstructions and SST-indicative proxies, we conclude that a relatively cold temperature anomaly in the Nordic Seas co-existed with a warm anomaly in the middle latitudes and in the subtropical-to-middle latitudes over the entire full-interglacial period of MIS 11c (Fig. 7). This steep meridional SST gradient over the eastern North Atlantic region was maintained at least until the subsequent glacial inception had started.

As indicated by modelling experiments, the North Atlantic spatial SST gradients are strongly related to the changes in atmospheric circulation via maintaining atmospheric pressure differences which affects evaporation and precipitation (Cayan, 1992; Deser and Blackmon, 1993; Rodwell et al., 1999). In general, a steep meridional SST gradient over the North Atlantic sector causes a zonal orientation of atmospheric circulation with weaker atmospheric pressure gradients between the Icelandic-low and Azores-high and a strengthened Hadley cell, altogether comprising a decreased NAO index (Hurrell, 1995; Felis et al., 2004; McCloskey and Knowles, 2009). In analogy, our MIS 11c SST reconstructions derived from the various geographical areas identify a SST pattern characteristic for this modern-day negative NAO mode (Rodwell et al., 1999). Nevertheless, the direct comparison between the modern atmospheric circulation and the one of MIS 11c period should still be applied with some caution since the specific geographical distribution of sea ice as well as remnants of ice sheets/caps in the polar north which might have had a profound influence on the particular position of the relevant atmospheric pressure cells (see also, Justino and Peltier, 2005).

Our assumption about a prevalence of the negative-like NAO mode during MIS 11c gains support from western Europe and the Iberian peninsula where pollen with reduced drought stress also indicate rather moist conditions during MIS 11c (Desprat et al., 2005 and references therein; Tzedakis et al., 2009), an environmental feature which was then associated with decreased strength in westerlies and a subzonal main direction of stormtrack pathways towards western Europe. Considering the effects of the NAO on meridional SST gradients, we can further assume that the early interglacial phase was characterized by lower NAO index in comparison to the late phase. This conclusion is in line with our finding of a more expanded sea-ice cover in the 
Age, ka

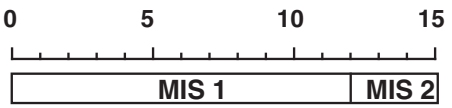

PS1243

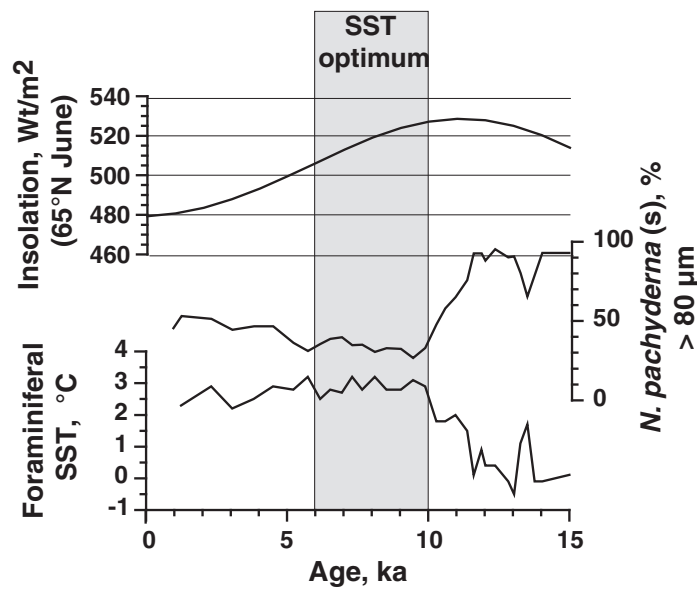

ODP 658

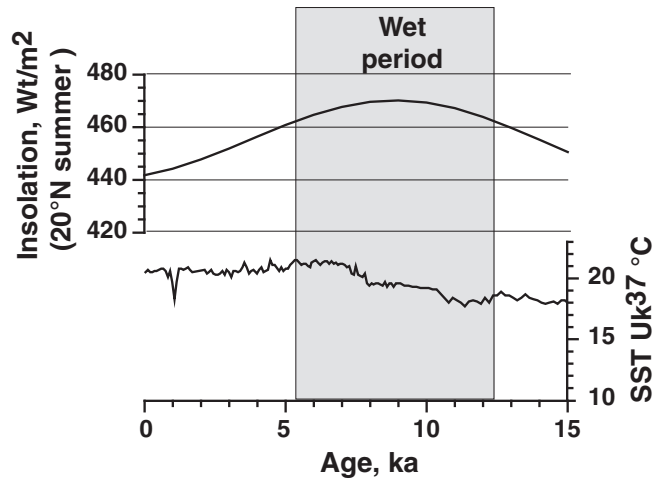

Age, ka

\begin{tabular}{|c|c|c|}
\hline MIS 10 & MIS 11 & MIS 12 \\
\hline
\end{tabular}

MD992277

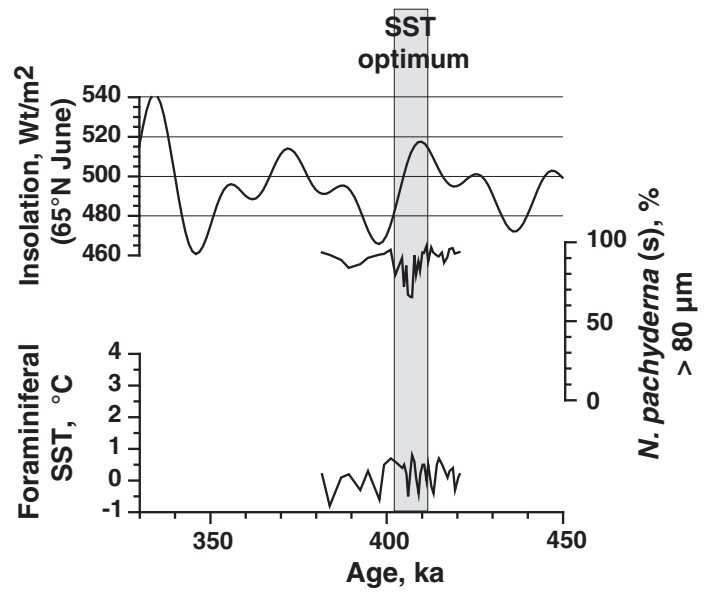

ODP 958

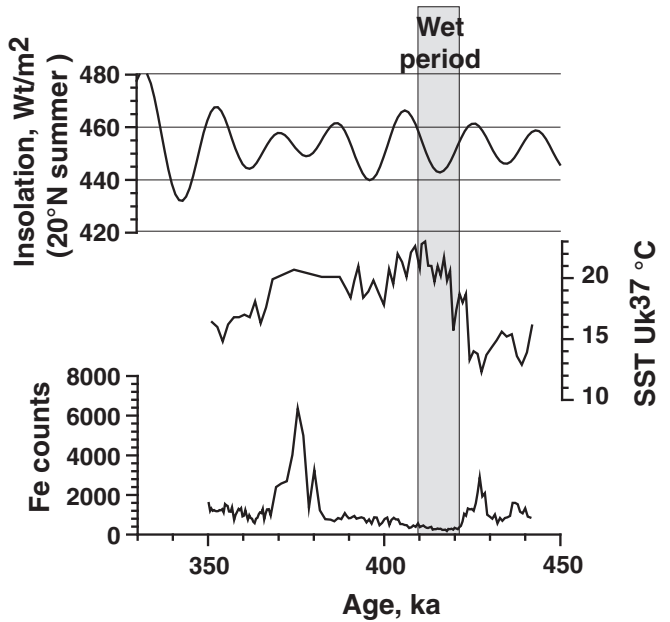

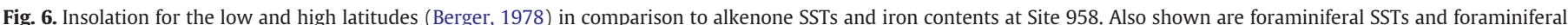

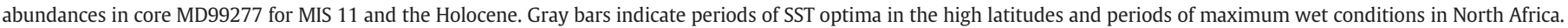
Stratigraphical subdivision is shown on the upper panel.

Nordic Seas at this time, conditions which are known to strongly impact NAO (Dickson et al., 2000; Magnusdottir et al., 2004).

A direct correlation between changes in NAO modes and the position of the ITCZ has not been verified through modelling experiments (McCloskey and Knowles, 2009) but it might be conceivable that a prevalence of the negative $\mathrm{NAO}^{-}$mode contributed to a prolonged maintenance of the wet conditions in the NW Africa during MIS 11c. Observational studies revealed anomalously strong rainfall in the Western Sahel during the 1950's and early 1960's, followed by a dry period since the 1970s, which corresponded to a strong dominance of the negative and positive NAO modes, respectively (Bader and Latif, 2003). Although the physical mechanism behind this relationship is still not fully understood, and changes in NAO oscillations and North Atlantic SST pattern are certainly not the sole mechanism influencing and modulating precipitation rates over West Africa, their considerable impact on this process has been indicated (Vizy and Cook, 2001, Bader and Latif, 2003).
The prevalence of a zonal atmospheric circulation type would also explain the somewhat contradictive SST dynamics between the polar and middle latitudes during MIS 11c which were especially pronounced during the early phase (Bauch et al., 2000; Bauch and Erlenkeuser, 2003; Helmke and Bauch, 2003; Kandiano and Bauch, 2007). Although the Nordic Seas still exhibited almost glacial-like conditions during the early phase of MIS 11c, at the same time our rare species analysis and SST reconstructions would reveal a strong advection of warm subtropical waters into the middle latitudes. Thus, our data corroborate the finding of enhanced intensity of the eastern boundary undercurrent in the North Atlantic during this period (Voelker et al., 2010). If a farther northward propagation of these warm waters was impeded by prolonged deglacial processes and sea-ice cover in the Polar North, an excess of rather warm water with enhanced salinities remained in the North Atlantic. This scenario would explain the higher planktic $\delta^{18} \mathrm{O}$ values and SSTs found in core M23414 for MIS 11c in comparison to the Holocene (Helmke and Bauch, 2003; Kandiano and Bauch, 2007). 
Table 4

SSTs during the Holocene and MIS 11c reported previously from other cores of the North Atlantic.

\begin{tabular}{|c|c|c|c|c|c|c|c|}
\hline \multirow{2}{*}{$\begin{array}{l}\text { Core/ODP } \\
\text { site }\end{array}$} & \multirow[t]{2}{*}{ Reference } & \multirow[t]{2}{*}{ Latitude } & \multirow[t]{2}{*}{ Longitude } & \multicolumn{2}{|c|}{ SST ${ }^{\circ} \mathrm{C}$ Holocene $0-11 \mathrm{ky}$} & \multicolumn{2}{|c|}{ SST MIS 11 398-420 ky } \\
\hline & & & & Average & Max & Average & Max \\
\hline MD01-2443 & Martrat et al. (2007) & $37^{\circ} 33.68^{\prime} \mathrm{N}$ & $10^{\circ} 08.53^{\prime} \mathrm{W}$ & 17.86 & 18.61 & 18.15 & 18.8 \\
\hline Site U1313 & Stein et al. (2009) & 41. $00^{\circ} \mathrm{N}$ & $32.957^{\circ} \mathrm{W}$ & 16.53 & 18.17 & 18.27 & 20.17 \\
\hline Site 982 & Lawrence et al. (2009) & $58^{\circ} \mathrm{N}$ & $16^{\circ} \mathrm{W}$ & 13.9 & 14.9 & 14.9 & 15.5 \\
\hline
\end{tabular}

At present, surface water salinities at site M23414 have lower values in comparison to the main axis of the NAC, which runs to the east of site M23414. Because site M23414 underlies the western edge of the NAC, surface waters here are diluted by lower saline waters from the west (Conkright et al., 2001). Thus, for MIS 11c we may invoke a westward deflection or expansion of the axis of the NAC, thereby also warming the subpolar gyre more than during the Holocene. Because an enhanced volume of warm water within the subpolar gyre should increase the heat budget over southern Greenland, our interpretation is in good agreement with a recent finding of relatively mild conditions in southern Greenland and the proposal of a diminished Greenland ice sheet during MIS 11c (de Vernal and Hillaire-Marcel, 2008).

By analogy with the modern situation, it might be further assumed that such surface ocean circulation promoted an intense deep water convection in the southern part of the Nordic seas. But, at the same time, deep water convection in the Labrador Sea might be impeded due to insufficient surface water influence from the Arctic on the one hand and a persistence of a warm water surface layer in the Labrador sea on the other (Dickson et al., 1996). However, such an assumption needs further support of modelling experiments.

\section{Summary and conclusions}

Employing sediment cores along a meridional transect within the northeastern Atlantic sector, ranging from polar to subtropical latitudes $\left(\sim 70\right.$ to $\left.20^{\circ} \mathrm{N}\right)$, we have investigated the regional SST dynamics across interglacial stage MIS 11c. According to our results on the basis of various foraminiferal data and SST estimates, two phases are clearly recognizable during the period when full-interglacial conditions prevailed, i.e. the interval after the main deglaciation of Termination $\mathrm{V}$ and before glacial inception (MIS 11c sensu stricto). An early phase (420 to $411 \mathrm{ka}$ ) which was characterized by a continuous rise in SSTs, and a late phase (411 to $398 \mathrm{ka}$ ) during which SSTs reached their maximum values. This timing in postglacial SST development after Termination V does not match the Holocene climate pattern when the optimum already began directly after the Termination I alongside with high-northern insolation.

According to our reconstructions a strong cold temperature anomaly persisted in the polar Nordic Seas region across MIS11c-ss, especially during its early phase, while at the same time a warm anomaly was characteristic in the western Mediterranean Sea and off NW Africa, altogether resulting in a steep meridional SST gradient over the eastern North Atlantic. By analogy with the present-day situation such a spatial SST pattern is akin to a negative NAO. Therefore, we suggest that, contrary to the modern climate situation with a dominantly positive NAO mode, the atmospheric circulation during MIS 11c had a more zonal orientation comparable to the modern negative NAO mode. The reason for it lies in the particular ocean properties in the polar latitudes. The long-lasting effects of meltwater from the waning, formerly very large northern ice sheets had a significant impact on the surface salinity in the Nordic seas, which promoted extensive seasonal sea-ice formation. Because of baroclinic effects associated with decreased salinity of the upper ocean layer in the Nordic seas, a northward propagation of warm Atlantic waters at the surface was impeded which eventually led to a westward displacement of the axis of the NAC. This conclusion is further supported by heavier planktic $\delta^{18} \mathrm{O}$ values and higher SSTs observed in core M23414 during MIS 11c than in the Holocene which also points to a higher surface salinity in this region due to enhanced influence of subtropical waters. The general inference of a more zonal atmospheric circulation during MIS11c is also corroborated by our upwelling/trade wind proxy records off NW Africa as well as the particular surface ocean reconstructions in the western Mediterranean Sea.
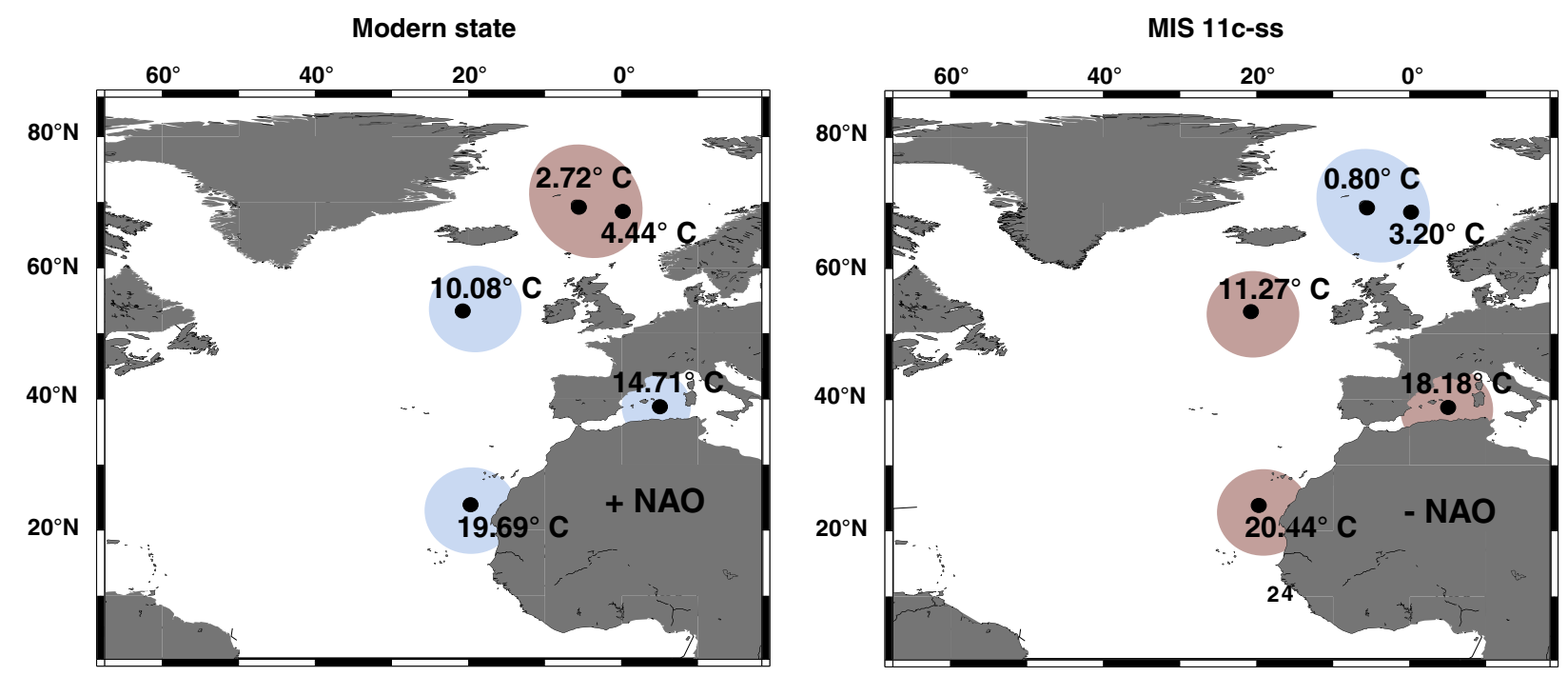

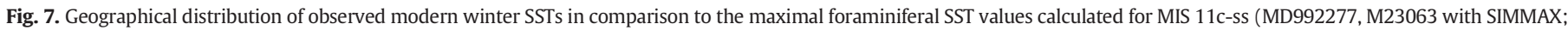

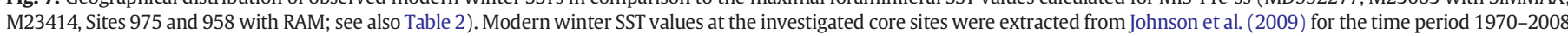
with a prevalence of a positive NAO mode. Cold and warm SST anomalies characteristic for positive and negative NAO modes are indicated by blue and pink circles, respectively. 
For both areas a long-lasting period of wet conditions is suggested for northern Africa for which an enhanced moisture supply via zonal transportation was at least partially responsible.

\section{Acknowledgments}

The authors are very grateful to Viktor Gouretski for a computation of the modern SST values. The manuscript has benefited from fruitful comments of Graziella Bozzano, Vladimir Semenov. The study was supported by Deutsche Forschung Gemeinschaft (DFG; Ba1367/8-1,2 PAINTER). All data presented in this paper are available at www. pangaea.de.

\section{References}

Adkins, J., DeMenocal, P., Eshel, G., 2006. The "African humid period" and the record of marine upwelling from excess Th-230 in Ocean Drilling Program Hole 658C. Paleoceanography 21.

Andersson, C., Pausata, F.S.R., Jansen, E., Risebrobakken, E., Telford, R.J., 2010. Holocene trends in the foraminifer record from the Norwegian Sea and the North Atlantic Ocean. Climate of the Past 6, 179-193.

Bader, J., Latif, M., 2003. The impact of decadal-scale Indian Ocean sea surface temperature anomalies on Sahelian rainfall and the North Atlantic Oscillation. Geophysica Research Letters 30, 2169.

Balsam, W.L., Otto-Bliesner, B.L., Deaton, B.C., 1995. Modern and Last Glacial Maximum Eolian sedimentation patterns in the Atlantic Ocean interpreted from sediment iron oxide content. Paleoceanography 10, 493-507.

Barash, M.S., 1988. Quaternary paleoceanography of the Atlantic Ocean. Nauka (in Russian) 272 (Moscow).

Bárcena, M.A., Flores, J.A., Sierro, F.J., PÃ@rez-Folgado, M., Fabres, J., Calafat, A., Canals, M. 2004. Planktonic response to main oceanographic changes in the Alboran Sea (Western Mediterranean) as documented in sediment traps and surface sediments. Marine Micropaleontology 53, 423-445.

Barnston, A.G., Livezey, R.E., 1987. Classification, seasonality and persistence of lowfrequency atmospheric circulation patterns. Monthly Weather Review 115, 1083-1126.

Bauch, H.A., 1994. Significance of variability in Turborotalita quinqueloba (Natland) test size and abundance for paleoceanographic interpretations in the Norwegian-Greenland Sea. Marine Geology 121, 129-141.

Bauch, H.A., 1997. Paleoceanography of the North Atlantic Ocean $\left(68^{\circ}-76^{\circ} \mathrm{N}\right)$ during the past 450 ky deduced from planktic foraminiferal assemblages and stable isotopes. In: Hass, H.C., Kaminski, M.A. (Eds.), Contributions to the Micropaleontology and Paleoceanography of the Northern North Atlantic. Grzybowski Foundation Special Publication, Krakow, pp. 83-100.

Bauch, H.A., Erlenkeuser, H., 2003. Interpreting glacial-interglacial changes in ice volume and climate from subarctic deep water foraminiferal $\delta^{18} \mathrm{O}$. In: Droxler, A.W., Poore, R.Z., Burckle, L.H. (Eds.), Earth's Climate and Orbital Eccentricity: The Marine Isotope Stage 11 Question. American Geophysical Union Monograph Series, Washington, D. C, pp. 83-102.

Bauch, H.A., Erlenkeuser, H., 2008. A "critical" climatic evaluation of last interglacial (MIS 5e) records from the Norwegian Sea. Polar Research 27, 135-151.

Bauch, H.A., Helmke, J.P., 1999. Glacial-interglacial records of the reflectance of sediments from the Norwegian-Greenland-Iceland Sea (Nordic Seas). International Journal of Earth Sciences 88, 325-336.

Bauch, H.A., Kandiano, E.S., 2007. Evidence for early warming and cooling in North Atlantic surface waters during the last interglacial. Paleoceanography 22. doi:10.1029/ 2005PA001252.

Bauch, H.A., Erlenkeuser, H., Helmke, J.P., Struck, U., 2000. A paleoclimatic evaluation of marine oxygen isotope stage 11 in the high-northern Atlantic (Nordic seas). Global and Planetary Change 24, 27-39.

Bauch, H.A., Struck, U., Thiede, J., 2001a. Planktic and benthic foraminifera as indicators for past ocean changes in surface and deep waters of the Nordic seas. In: Schäfer, P. Ritzrau, W., Schlüter, M., Thiede, J. (Eds.), The Northern North Atlantic: a changing environment. Springer-Verlag, New York, pp. 411-421.

Bauch, H.A., Erlenkeuser, H., Spielhagen, R., Struck, U., Matthiessen, J., Thiede, J., Heinemeier, J., 2001b. A multiproxy reconstruction of the evolution of deep and surface waters in the subarctic Nordic seas over the last 30,000 years. Quaternary Science Reviews 20, 659-678.

Berger, A., 1978. Long-term variations of daily insolation and Quaternary climatic changes. Journal of Atmospheric Sciences 35, 2362-2367.

Berger, A., Loutre, M.F., 2002. An exceptionally long interglacial ahead? Science 297, 1287-1288.

Billups, K., Chaisson, W., Worsnopp, M., Thunell, R., 2004. Millennial-scale fluctuations in subtropical northwestern Atlantic surface ocean hydrography during the mid-Pleistocene. Paleoceanography 19, PA2017.

Bonelli, S., Charbit, S., Kageyama, M., Woillez, M.-N., Ramstein, G., Dumas, C., Quiquet, A. 2009. Investigating the evolution of major Northern Hemisphere ice sheets during the last glacial-interglacial cycle. Climate of the Past 5, 329-345.

Bout-Roumazeilles, V., Combourieu Nebout, N., Peyron, O., Cortijo, E., Landais, A., MassonDelmotte, V., 2007. Connection between South Mediterranean climate and North African atmospheric circulation during the last 50,000 yr BP North Atlantic cold events. Quaternary Science Reviews 26, 3197-3215.
Brassell, S.C., Eglinton, G., Marlowe, I.T., Pflaumann, U., Sarnthein, M., 1986. Molecular stratigraphy; a new tool for climatic assessment. Nature (London) 320 (6058), 129-133.

Cacho, I., Grimalt, J.O., Pelejero, C., Canals, M., Sierro, F.J., Flores, J.A., Shackleton, N., 1999. Dansgaard-Oeschger and Heinrich Event Imprints in Alboran Sea Paleotemperatures. Paleoceanography 14, 698-705.

Calvo, E., Grimalt, J., Jansen, E., 2002. High resolution $\mathrm{U}^{\mathrm{k}}{ }_{37}$ sea surface temperature reconstruction in the Norwegian Sea during the Holocene. Quaternary Science Reviews 21, 1385-1394.

Cayan, D.R., 1992. Latent and sensible heat flux anomalies over the northern oceans: the connection to monthly atmospheric circulation. Journal of Climate 5, 354-369.

Chiang, J.C.H., Bitz, C.M., 2005. Influence of high latitude ice cover on the marine Intertropical Convergence Zone. Climate Dynamics 25, 477-496.

Claussen, M., Kubatzki, C., Brovkin, V., Ganopolski, A., Hoelzmann, P., Pachur, H.J., 1999. Simulation of an abrupt change in Saharan vegetation in the mid-Holocene. Geophysical Research Letters 26, 2037-2040.

Conkright, M.E., Locarnini, R.A., Garcia, H.E., O'Brien, T.D., Boyer, T.P., Stephens, C., Antonov, J.I., 2001. World Ocean Atlas 2001.

Conte, M.H., Eglinton, G., 1993. Alkenone and alkenoate distributions within the euphotic zone of the eastern North Atlantic: correlation with production temperature. Deep-Sea Research I 40 (10), 1935-1961.

de Abreu, L., Abrantes, F.F., Shackleton, N.J., Tzedakis, P.C., McManus, J.F., Oppo, D.W., Hall, M.A., 2005. Ocean climate variability in the eastern North Atlantic during interglacial marine isotope stage 11: a partial analogue to the Holocene? Paleoceanography 20, PA3009. doi:10.1029/2004PA001091.

de Vargas, C., Renaud, S., Hilbrecht, H., Pawlowski, J., 2001. Pleistocene adaptive radiation in Globorotalia truncatulinoides: genetic, morphologic, and environmental evidence. Paleobiology 27, 104-125.

de Vernal, A., Hillaire-Marcel, C., 2008. Natural variability of Greenland climate, vegetation, and ice volume during the past million years. Science 320, 1622-1625.

deMenocal, P., Ortiz, J., Guilderson, T., Sarnthein, M., 2000a. Coherent high- and low-latitude climate variability during the Holocene warm period. Science 288, 2198-2202.

deMenocal, P., Ortiz, J., Guilderson, T., Adkins, J., Sarnthein, M., Baker, L., Yarusinsky, M., 2000b. Abrupt onset and termination of the African Humid Period: rapid climate responses to gradual insolation forcing. Quaternary Science Reviews 19, 347-361.

Deser, C., Blackmon, M.L., 1993. Surface climate variations over the North Atlantic Ocean during winter: 1900-1989. Journal of Climate 6, 1743-1753.

Desprat, S., Sánchez Goñi, M.F., Turon, J.-L., McManus, J.F., Loutre, M.F., Duprat, J., Malaizé, B., Peyron, O., Peypouquet, J.-P., 2005. Is vegetation responsible for glacial inception during periods of muted insolation changes? Quaternary Science Reviews 24, 1361-1374.

Dickson, R., Lazier, J., Meincke, J., Rhines, P., Swift, J., 1996. Long-term coordinated changes in the convective activity of the North Atlantic. Progress in Oceanography 38, 241-295.

Dickson, R.R., Osborn, T.J., Hurrell, J.W., Meincke, J., Blindheim, J., Adlandsvik, B., Vinje, T., Alekseev, G., Maslowski, W., 2000. The Arctic Ocean response to the North Atlantic Oscillation. Journal of Climate 13, 2671-2696.

Dokken, T.D., Jansen, E., 1999. Rapid changes in the mechanism of ocean convection during the last glacial period. Nature 401, 458-461.

Donner, J., 1995. The Quaternary History of Scandinavia. Cambridge University Press, New York

EPICA, Community, and Members, 2004. Eight glacial cycles from an Antarctic ice core. Nature 429, 623-628.

Felis, T., Lohmann, G., Kuhnert, H., Lorenz, S.J., Scholz, D., Patzold, J., Al-Rousan, S.A., Al-Moghrabi, S.M., 2004. Increased seasonality in Middle East temperatures during the last interglacial period. Nature 429, 164-168.

Fischer, G., Donner, B., V., R., Davenport, R., Wefer, G., 1996. Distinct year-to-year particle flux variations off Cape Blanc during 1988-1991: relation to $\delta^{18} \mathrm{O}$-deduced sea-surface temperatures and trade winds. Journal of Marine Research 54, 73-98.

Healey, S., Thunell, R., 2004. Millennial-scale variability in western subtropical North Atlantic surface and deep water circulation during marine isotope stages 11 and 12. Paleoceanography 19, PA1013. doi:10.1029/2003PA000925.

Hearty, P.J., Kindler, P., Cheng, H., Edwards, R.L., 1999. A + 20 m middle Pleistocene sea-level highstand (Bermuda and the Bahamas) due to partial collapse of Antarctic ice. Geology 27, 375-378.

Helmke, J.P., Bauch, H.A., 2001. Glacial-interglacial relationship between carbonate components and sediment reflectance in the North Atlantic. Geo-Marine Letters 21, 16-22.

Helmke, J.P., Bauch, H.A., 2003. Comparison of glacial and interglacial conditions between the polar and subpolar North Atlantic region over the last five climatic cycles. Paleoceanography 18.

Helmke, J.P., Bauch, H.A., Röhl, U., Mazaud, A., 2005. Changes in sedimentation patterns of the Nordic seas region across the mid-Pleistocene. Marine Geology 215, 107-122.

Helmke, J.P., Bauch, H.A., Röhl, U., Kandiano, E.S., 2008. Uniform climate development between the subtropical and subpolar Northeast Atlantic across marine isotope stage 11. Climate of the Past 4, 433-457.

Herman, Y., 1972. Globorotalia truncatulinoides: a palaeo-oceanographic Indicator. Nature 238, 394-396.

Hughes, P., Barton, E.D., 1974. Stratification and water mass structure in the upwelling area off N. W. Africa in April-May 1969. Deep Sea Research 21, 611-628.

Hurrell, J.W., 1995. Decadal trends in the North-Atlantic Oscillation-regional temperatures and precipitation. Science 269, 676-679.

Hutson, W.H., 1980. The Agulhas current during the late Pleistocene: analysis of modern faunal analogs. Science 207, 64-66.

Imbrie, J., Berger, A., Boyle, E.A., Clemens, S.C., Duffy, A., Howard, W.R., Kukla, G., Kutzbach, J., Martinson, D.G., McIntyre, A., Mix, A.C., Molfino, B., Morley, J.J., Peterson, L.C., Pisias, N.G., Prell, W.L., Raymo, M.E., Shackleton, N.J., Toggweiler, J.R., 
1993. On the structure and origin of major glaciation cycles 2 . The 100,000 -year cycle. Paleoceanography 8, 699-735.

Jimenez-Espejo, F.J., Martinez-Ruiz, F., Rogerson, M., González-Donoso, J.M., Romero, O.E., Linares, D., Sakamoto, T., Gallego-Torres, D., Rueda Ruiz, J.L., Ortega-Huertas, M., Perez Claros, J.A., 2008. Detrital input, productivity fluctuations, and water mass circulation in the westernmost Mediterranean Sea since the Last Glacial Maximum. Geochemistry, Geophysics, Geosystems 9, Q11U02. doi:10.1029/2008GC002096.

Johannessen, T., Jansen, E., Flatoy, A., Ravelo, A.C., 1994. The relationship between surface water masses, oceanographic fronts and paleoclimatic proxies in surface sediments of the Greenland, Iceland, Norwegian Seas. In: Zahn, R., Pedersen, T.F., Kaminski, M.A., Labeyrie, L. (Eds.), Carbon Cycling in the Glacial Ocean: Constrains of the Oceans's Role in Global Change. Springer, Berlin, pp. 61-85.

Johnson, J., Stevens, I., 2000. A fine resolution model of the eastern North Atlantic between the Azores, the Canary Islands and the Gibraltar Strait. Deep Sea Research Part I: Oceanographic Research Papers 47, 875-899.

Johnson, D.R., Boyer, T.P., Garcia, H.E., Locarnini, R.A., Baranova, O.K., Zweng, M.M., 2009. World Ocean Database 2009 Documentation. In: Levitus, Sydney (Ed.), NODC Internal Report, 20. NOAA Printing Office, Silver Spring, MD. 175 pp.

Jones, P.D., Jonsson, T., Wheeler, D., 1997. Extension to the North Atlantic Oscillation using early instrumental pressure observations from Gibraltar and South-West Iceland. International Journal of Climatology 17, 1433-1450.

Justino, F., Peltier, W.R., 2005. The glacial North Atlantic Oscillation. Geophysical Research Letters 32.

Kandiano, E.S., Bauch, H.A., 2002. Implications of planktic foraminiferal size fractions for the glacial-interglacial paleoceanography of the polar North Atlantic. Journal of Foraminiferal Research 32, 245-251.

Kandiano, E.S., Bauch, H.A., 2003. Surface ocean temperatures in the Northeast Atlantic during the last 500,000 years: evidence from foraminiferal census data and iceberg-rafted debris. Terra Nova 15, 265-271.

Kandiano, E.S., Bauch, H.A., 2007. Phase relationship and surface water mass change in the NorthEast Atlantic during Marine Isotope stage 11 (MIS 11). Quaternary Research 68, 445-455.

Keigwin, L.D., Pickart, R.S., 1999. Slope water current over the Laurentian fan on interannual to millennial time scales. Science 286, 520-523.

Kim, J.-H., Rimbu, N., Lorenz, S.J., Lohmann, G., Nam, S.-I., Schouten, S., Rühlemann, C., Schneider, R.R., 2004. North Pacific and North Atlantic sea-surface temperature variability during the Holocene. Quaternary Science Reviews 23, 2141-2154.

Kucera, M., Weinelt, M., Kiefer, T., Pflaumann, U., Hayes, A., Weinelt, M., Chen, M.-T., Mix, A.C., Barrows, T.T., Cortijo, E., Duprat, J., Juggins, S., Waelbroeck, C., 2005. Reconstruction of sea-surface temperatures from assemblages of planktonic foraminifera: multitechnique approach based on geographically constrained calibration data sets and its application to glacial Atlantic and Pacific Oceans. Quaternary Science Reviews Multiproxy Approach for the Reconstruction of the Glacial Ocean surface 24, 951-998.

Lawrence, K.T., Herbert, T.D., Brown, C.M., Raymo, M.E., Haywood, A.M., 2009. Highamplitude variations in North Atlantic sea surface temperature during the early Pliocene warm period. Paleoceanography 24.

Levitus, S., Boyer, T.P., 1994. World Ocean Atlas 1994: Temperature. NOAA Atlas NESDIS 4. U.S. Department of Commerce, Washington, D.C, p. 117.

Li, X.S., Berger, A., Loutre, M.F., Maslin, M.A., Haug, G.H., Tiedemann, R., 1998. Simulating Late Pliocene northern hemisphere climate with the LLN 2-D Model. Geophysical Research Letters 25, 915-918.

Lisiecki, L.E., Raymo, M.E., 2005. A Plio-Pleistocene stack of 57 globally distributed benthic $\delta^{18} \mathrm{O}$ records. Paleoceanography 20. doi:10.1029/2004PA001071.

Loutre, M.F., Berger, A., 2003. Marine isotope stage 11 as an analogue for the present interglacial. Global and Planetary Change 36, 209-217.

Magnusdottir, G., Deser, C., Saravanan, R., 2004. The effects of North Atlantic SST and sea ice anomalies on the winter circulation in CCM3. Part I: main features and storm track characteristics of the response. Journal of Climate 17, 857-876.

Martinez, J.I., Mora, G., Barrows, T.T., 2007. Paleoceanographic conditions in the western Caribbean Sea for the last 560 kyr as inferred from planktonic foraminifera. Marine Micropaleontology 64, 177-188.

Martrat, B., Grimalt, J.O., Shackleton, N.J., de Abreu, L., Hutterly, M.A., Stocker, T.F., 2007. Four climate cycles of recurring deep and surface water destabilizations on the Iberian margin. Science 317, 502-507.

Marzin, C., Braconnot, P., 2009. The role of the ocean feedback on Asian and African monsoon variations at $6 \mathrm{kyr}$ and $9.5 \mathrm{kyr}$ BP. Comptes Rendus Geoscience 341, 643-655.

McCloskey, T.A., Knowles, J.T., 2009. Migration of the tropical cyclone zone throughout the Holocene. In: Elsner, J.B., GJagger, T.H. (Eds.), Hurricanes and Climate Change. Springer Science, pp. 169-187.

McIntyre, A., Ruddiman, W.F., Karlin, K., Mix, A.C., 1989. Surface water response of the equatorial Atlantic Ocean to orbital forcing. Paleoceanography 4, 19-55.

McManus, J.F., Oppo, D.W., Cullen, J.L., 1999. A 0.5-million-year record of millennial-scale climate variability in the North Atlantic. Science 283, 971-975.

McManus, J., Oppo, D., Cullen, J., Healey, S., 2003. Marine isotope stage 11 (MIS 11): analog for Holocene and future climate? In: Droxler, A.W., Poore, R.Z., Burckle, L.H. (Eds.), Earth's Climate and Orbital Eccentricity: The Marine Isotope Stage 11 Question. American Geophysical Union Monograph Series, Washington, D.C, pp. 69-85.

Müller, P.J., Kirst, G., Ruhland, G., von Storch, I., Rosell-Mele, A., 1998. Calibration of the alkenone paleotemperature index $\mathrm{U} 37 \mathrm{~K}^{\prime}$ based on core-tops from the eastern South Atlantic and the global ocean $\left(60^{\circ} \mathrm{N}-60^{\circ} \mathrm{S}\right)$. Geochimica et Cosmochimica Acta 62, 1757-1772.

Nitychoruk, J., Binka, K., Hoefs, J., Ruppert, H., Schneider, J., 2005. Climate reconstruction for the Holsteinian Interglacial in eastern Poland and its comparison with isotopic data from Marine Isotope Stage 11. Quaternary Science Reviews 24, 631-644.
Nykjær, L., van Camp, L., 1994. Seasonal and interannual variability of coastal upwelling along northwest Africa and Portugal from 1981 to 1991. Journal of Geophysical Research 99, 14197-14207.

Oppo, D.W., McManus, J.F., Cullen, J.L., 1998. Abrupt climatic events 500,000 to 340,000 years ago: evidence from subpolar North Atlantic sediments. Science 297, 1335-1338.

Osborn, T.J., 2006. Recent variations in the winter North Atlantic Oscillation. Weather 61, 353-355.

Pérez-Folgado, M., Sierro, F.J., Flores, J.A., Cacho, I., Grimalt, J.O., Zahn, R., Shackleton, N. 2003. Western Mediterranean planktonic foraminifera events and millennial climatic variability during the last $70 \mathrm{kyr}$. Marine Micropaleontology 48, 49-70.

Petit, J.R., Jouzel, J., Raynaud, D., Barkov, N.I., Barnola, J.-M., Basile, I., Bender, M. Chappellaz, J., Davis, M., Delaygue, G., Delmotte, M., Kotlyakov, V.M., Legrand, M. Lipenkov, V.Y., Lorius, C., PEpin, L., Ritz, C., Saltzman, E., Stievenard, M., 1999. Climate and atmospheric history of the past 420,000 years from the Vostok ice core, Antarctica. Nature 399, 429-436.

Pflaumann, U., Duprat, J., Pujol, C., Labeyrie, L.D., 1996. SIMMAX: a modern analog technique to deduce Atlantic sea surface temperatures from planktonic foraminifera in deep-sea sediments. Paleoceanography 11, 15-35.

Pflaumann, U., Sarnthein, M., Ficken, K., Grothmann, A., Winkler, A., 1998. Variations in eolian and carbonate sedimentation, sea-surface temperature, and productivity over the last 3 m.y. at Site 958 off Northwest Africa. In: Firth, J.V. (Ed.), Proceedings of the Ocean Drilling Program, Scientific Results: College Station, TX, 159T, pp. 3-16.

Pflaumann, U., Sarnthein, M., Chapman, M., de Abreu, L., Funnel, B., Huels, M., Kiefer, T., Maslin, M., Schulz, H., Swallow, J., van Kreveld, S., Vautravers, M., Vogelsang, E. Weinelt, M., 2003. Glacial North Atlantic: Sea-surface conditions reconstructed by CLAMAP 2000. Paleoceanography 18, 1065. doi:10.1029/2002PA000774.

Pierre, C., Belanger, P., Saliège, J.F., Urrutiaguer, M.J., Murat, A., 1999. Paleoceanography of the western Mediterranean during the Pleistocene: oxygen and carbon isotope records at Site 975. In: Zahn, R., Comas, M.C., Klaus, A. (Eds.), Proceedings of the Ocean Drilling Program, pp. 481-488.

Prahl, F.G., Wakeham, S.G., 1987. Calibration of unsaturation patterns in long-chain ketone compositions for palaeotemperature assessment. Nature (London) 330 (6146), 367-369.

Prell, W.L., 1985. The stability of low latitude sea surface temperatures: An evaluation of the CLIMAP reconstruction with emphasis on positive SST anomalies. U.S. Dept of Energy, Washington D.C.

Prell, W.L., Kutzbach, J.E., 1987. Monsoon variability over the past 150,000 years. Journal of Geophysical Research 92, 8411-8425

Pujol, C., Grazzini, C.V., 1995. Distribution patterns of live planktic foraminifers as related to regional hydrography and productive systems of the Mediterranean-Sea. Marine Micropaleontology 25, 187-217.

Rasmussen, T.L., Balbon, E., Thomsen, E., Labeyrie, L., van Weering, T.C.E., 1999. Climate records and changes in deep outflow from the Norwegian Sea B150-55 ka. Terra Nova 11, 61-66.

Raynaud, D., Barnola, J.-M., Souchez, R., Lorrain, R., Petit, J.-R., Duval, P., Lipenkov, V.Y. 2005. The record for marine isotopic stage 11. Nature 436, 39-40.

Richter, T.O., Van der Gast, S., Koster, R., Vaars, A., Gieles, R., De Stigter, H.C., De Haas, H. VanWeering, T.C.E., 2006. The Avaatech XRF Core Scanner: technical description and applications to NE Atlantic sediments. In: Rothwell, R.G. (Ed.), New Techniques in Sediments Core Analysis. Geological Society London, Special Publication, London, pp. 39-51.

Rimbu, N., Lohmann, G., Kim, J.-H., Arz, H.W., Schneider, R., 2003. Arctic/North Atlantic Oscillation signature in Holocene sea surface temperature trends as obtained from alkenone data. Geophysical Research Letters 30, 1280.

Rodrigues, T., Voelker, A.H.L., Grimalt, J.O., Abrantes, F., Naughton, F., 2011. Iberian Margin sea surface temperature during MIS 15 to 9 (580-300 ka): glacial suborbital variability versus interglacial stability. Paleoceanography 26.

Rodwell, M.J., Rowell, D.P., Folland, C.K., 1999. Oceanic forcing of the wintertime North Atlantic Oscillation and European climate. Nature 398, 320-323.

Rogerson, M., Cacho, I., Jimenez-Espejo, F., Reguera, M.I., Sierro, F.J., Martinez-Ruiz, F., Frigola, J. Canals, M., 2008. A dynamic explanation for the origin of the western Mediterranean organic-rich layers. Geochemistry, Geophysics, Geosystems 9 Q07U01. doi:10.1029/2007GC001936.

Röhl, U., Abrams, L.J., 2000. High-resolution, downhole and non-destructive core measurements from Sites 999 and 1001 in the Caribbean Sea: application to the Late Paleocene Thermal Maximum. Proceedings of the Ocean Drilling Program (ODP). : Scientific Results, 165. Ocean Drilling Program, College Station, TX, pp. 191-203.

Rohling, E.J., Fenton, M., Jorissen, F.J., Bertrand, P., Ganssen, G., Caulet, J.P., 1998 Magnitudes of sea-level lowstands of the past 500,000 years. Nature $394,162-165$

Rosell-Melé, A. Carter, J., Eglinton, G. 1994. Distributions of long-chain alkenones and alkyl alkenoates in marine surface sediments from the North East Atlantic Advances in Organic Geochemistry 1993; Proceedings of the 16th International Meeting on Organic Geochemistry. Pergamon, Oxford-New York, International, pp. 501-509.

Rosell-Mele, A., Eglinton, G., Pflaumann, U., Sarnthein, M., 1995. Atlantic core-top calibration of the U37K index as a sea-surface palaeotemperature indicator. Geochimica et Cosmochimica Acta 59, 3099-3107.

Ruddiman, W.F., Raymo, M.E., Martinson, D.G., Clement, B.M., Backman, J., 1989. Pleistocene evolution: Northern Hemisphere ice sheets and North Atlantic Ocean. Paleoceanography $4,353-412$

Salgueiro, E. Voelker, A., Abrantes, F., Meggers, H., Pflaumann, U., Loncaric, N. Gonzalez-Alvarez, R., Oliveira, P., Bartels-Jonsdottir, H.B., Moreno, J., Wefer, G., 2008. Planktonic foraminifera from modern sediments reflect upwelling patterns off Iberia: insights from a regional transfer function. Marine Micropaleontology 66, 135-164. 
Schefuß, E., Schouten, S., Jansen, J.H.F., Sinninghe Damste, J.S., 2003. African vegetation controlled by tropical sea surface temperatures in the mid-Pleistocene period. Nature $422,418-421$.

Schmuker, B., Schiebel, R., 2002. Planktic foraminifers and hydrography of the eastern and northern Caribbean Sea. Marine Micropaleontology 46, 387-403.

Semenov, V.A., Latif, M., Jungclaus, J.H., Park, W., 2008. Is the observed NAO variability during the instrumental record unusual? Geophysical Research Letters 35. doi:10.1029/2008GL033273.

Stein, R., Hefter, J., Grützner, J., Voelker, A., Naafs, B.D.A., 2009. Variability of surface water characteristics and Heinrich-like events in the Pleistocene midlatitude North Atlantic Ocean: biomarker and XRD records from IODP Site U1313 (MIS 16-9). Paleoceanography 24, PA2203.

Tiedemann, R., Sarnthein, M., Shackleton, N.J., 1994. Astronomic timescale for the Pliocene Atlantic $\delta^{18} \mathrm{O}$ and dust flux records of Ocean Drilling Program Site 659. Paleoceanography 9, 619-638.

Tjallingii, R., Claussen, M., Stuut, J.-B.W., Fohlmeister, J., Jahn, A., Bickert, T., Lamy, F., Rohl, U., 2008. Coherent high- and low-latitude control of the northwest African hydrological balance, 1, pp. 670-675.

Tuenter, E., Weber, S.L., Hilgen, F.J., Lourens, L.J., 2003. The response of the African summer monsoon to remote and local forcing due to precession and obliquity. Global and Planetary Change 36, 219-235.

Tzedakis, P.C., Palike, H., Roucoux, K.H., de Abreu, L., 2009. Atmospheric methane southern European vegetation and low-mid latitude links on orbital and millennial timescales. Earth and Planetary Science Letters 277, 307-317.

Van Nieuwenhove, N., Bauch, H.A., Eynaud, F., Kandiano, E., Cortijo, E., Turon, J.-L., 2011 Evidence for delayed poleward expansion of North Atlantic surface waters during the last interglacial (MIS 5e). Quaternary Science Reviews 30, 934-946.
Veum, T., Jansen, E., Arnold, M., Beyer, I., Duplessy, J.-C., 1992. Water mass exchange between the North Atlantic and the Norwegian Sea during the past 28,000 years. Nature 356, 783-785.

Vinje, T., 2001. Anomalies and trends of sea-ice extent and atmospheric circulation in the Nordic Seas during the Period 1864-1998. Journal of Climate 14, 255-267.

Vizy, E.K., Cook, K.H., 2001. Mechanisms by which Gulf of Guinea and eastern North Atlantic sea surface temperature anomalies can influence African rainfall. Journal of Climate 14, 795-821.

Voelker, A.H.L., Rodrigues, T., Stein, R., Hefter, J., Billups, K., Oppo, D., McManus, J., Grimalt, J.O., 2010. Variations in mid-latitude North Atlantic surface water properties during the mid-Brunhes (MIS 9-14) and their implications for the thermohaline circulation. Climate of the Past 6, 531-552.

Vogelsang, E., 1990. Paläo-Ozanographie des Europäischen Nordmeeres anhand stabiler Kohlenstoff-und Sauerstoffisotope. Berichte aus dem Sonderforschungsbereich 313 (23), 1-137.

Waelbroeck, C., Labeyrie, L., Duplessy, J.-C., Guiot, J., Labracherie, M., Leclaire, H., Duprat, J., 1998. Improving past sea surface temperature estimates based on planktonic fossil faunas. Paleoceanography 13, 272-283.

Weldeab, S., Lea, D.W., Schneider, R.R., Andersen, N., 2007. 155,000 years of West African monsoon and ocean thermal evolution. Science 316, 1303-1307.

Wooster, W.S., Bakum, A., McLain, D.R., 1976. The seasonal upwelling cycle along the eastern boundary of the North Atlantic. Journal of Marine Research 34, 131-140.

Zhao, M., Beveridge, N.A.S., Shackleton, N.J., Sarnthein, M., Eglinton, G., 1995. Molecular stratigraphy of cores off northwest Africa: sea surface temperature history over the last 80 ka. Paleoceanography 10, 661-675. 